University of Wollongong

Research Online

Faculty of Engineering and Information

Faculty of Engineering and Information

Sciences - Papers: Part B

Sciences

2019

\title{
3-E analysis and optimization of an organic rankine flash cycle integrated with a PEM fuel cell and geothermal energy
}

Zhixiong $\mathrm{Li}$

University of Wollongong, lizhixio@uow.edu.au

Shoaib Khanmohammadi

Saber Khanmohammadi

Abdullah Al-Rashed

Pouria Ahmadi

See next page for additional authors

Follow this and additional works at: https://ro.uow.edu.au/eispapers1

Part of the Engineering Commons, and the Science and Technology Studies Commons

Research Online is the open access institutional repository for the University of Wollongong. For further information contact the UOW Library: research-pubs@uow.edu.au 


\title{
3-E analysis and optimization of an organic rankine flash cycle integrated with a PEM fuel cell and geothermal energy
}

\author{
Abstract \\ 2019 Hydrogen Energy Publications LLC The current research deals with thermodynamic and economic \\ analyses and optimization of a geothermal system integrated with organic Rankine flash cycle (ORFC) \\ and a polymer electrolyte membrane fuel cell (PEM-FC). A thermodynamic model for ORFC and PEM-FC is \\ developed to investigate employing the PEM-FC in a combined geothermal ORFC. A comparative study is \\ carried out to determine the effect of applying PEM-FC in a geothermal based ORFC. The validation of \\ PEM-FC simulation with experimental data from the literature shows a good agreement. The results of \\ numerical modeling indicate that using the rejected heat in the PEM-FC instead of the low-temperature \\ geothermal source can increase the net output power from $254.9 \mathrm{~kW}$ to $1628.9 \mathrm{~kW}$ and the exergy \\ efficiency from $23.77 \%$ to $36.19 \%$, in the case of R123 as working fluid for the ORC system. Furthermore, \\ using the PEM-FC imposes $9.07 \mathrm{US} \$ \mathrm{~h}$ cost rate to the system. Additionally the parametric study shows \\ that the net output power and the total cost rate of the system are two major objective functions for the \\ optimization. Thus, a multi-objective genetic algorithm is applied to determine the optimal values of \\ design parameters with respect to some practical constraints. The results of the multi-criteria \\ optimization represent that the optimum value of decision variables with considered objective functions \\ are $\mathrm{T} 1=116^{\circ} \mathrm{C}$, rflash $=0.55, \mathrm{PFC}=230 \mathrm{kPa}$, and $\mathrm{P} 4=1208.4 \mathrm{kPa}$. \\ Disciplines \\ Engineering | Science and Technology Studies

\section{Publication Details} \\ Li, Z., Khanmohammadi, S., Khanmohammadi, S., Al-Rashed, A., Ahmadi, P. \& Afrand, M. (2019). 3-E \\ analysis and optimization of an organic rankine flash cycle integrated with a PEM fuel cell and geothermal \\ energy. International Journal of Hydrogen Energy,

\section{Authors} \\ Zhixiong Li, Shoaib Khanmohammadi, Saber Khanmohammadi, Abdullah Al-Rashed, Pouria Ahmadi, and \\ Masoud Afrand
}




\title{
3-E analysis and optimization of an organic Rankine flash cycle integrated with a PEM fuel cell and geothermal energy
}

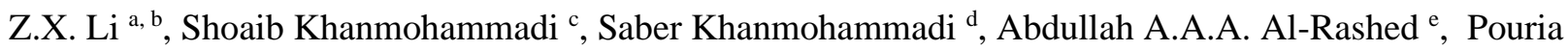 \\ Ahmadi ${ }^{\mathrm{*}}$, Masoud Afrand ${ }^{\mathrm{g}, \mathrm{h} \dagger}$ \\ a Ocean College, Minjiang University Fuzhou 350108, China \\ ${ }^{\mathrm{b}}$ State Key Laboratory of Hydraulic Engineering Simulation and Safety, Tianjin University Tianjin, 300350, China \\ ${ }^{\mathrm{c}}$ Department of Mechanical Engineering, Kermanshah University of Technology, Kermanshah, Iran \\ ${ }^{\mathrm{d}}$ Faculty of Mechanical Engineering and the Energy Research Institute, University of Kashan, Iran \\ ${ }^{\mathrm{e}}$ Department of Automotive and Marine Engineering Technology, College of Technological Studies, The Public \\ Authority for Applied Education and Training, Kuwait \\ ${ }_{\mathrm{f}}^{\mathrm{f}}$ Institute for Sustainability, Energy, and Environment (iSEE), University of Illinois at Urbana-Champaign (UIUC), \\ Urbana, IL, USA, 61802 \\ ${ }^{g}$ Laboratory of Magnetism and Magnetic Materials, Advanced Institute of Materials Science, Ton Duc Thang \\ University, Ho Chi Minh City, Vietnam \\ ${ }^{\text {h }}$ Faculty of Applied Sciences, Ton Duc Thang University, Ho Chi Minh City, Vietnam
}

\begin{abstract}
The current research deals with thermodynamic and economic analyses and optimization of a geothermal system integrated with organic Rankine flash cycle (ORFC) and a polymer electrolyte membrane fuel cell (PEM-FC). A thermodynamic model for ORFC and PEM-FC is developed to investigate the employing the PEM-FC in a combined geothermal ORFC. Comparative study is carried out to determine the effect of applying PEM-FC in a geothermal based ORFC. The validation of PEM-FC simulation with experimental data from literature shows a good agreement. The results of numerical modeling indicate that using the rejected heat in the PEM-FC instead of
\end{abstract}

* Email address: Pahmadi@illinois.edu 
the low-temperature geothermal source can increase the net output power from $254.9 \mathrm{~kW}$ to 1628.9 $\mathrm{kW}$ and the exergy efficiency from $23.77 \%$ to $36.19 \%$, in the case of R123 as working fluid for the ORC system. Furthermore, using the PEM-FC imposes $9.07 \mathrm{US} \$ / \mathrm{h}$ cost rate to the system. Additionally the parametric study shows that that the net output power and the total cost rate of the system are two major objective functions for the optimization. Thus, a multi-objective genetic algorithm is applied to determine the optimal values of design parameters with respect to some practical constraints. The results of the multi-criteria optimization represents that the optimum value of decision variables with considered objective functions are $T_{1}=116{ }^{\circ} \mathrm{C}, r_{\text {flash }}=$ $0.55, P_{F C}=230 \mathrm{kPa}$, and $P_{4}=1208.4 \mathrm{kPa}$.

Key words: Geothermal energy; PEM-FC; thermo-economic; multi-objective optimization

\begin{tabular}{|ll|}
\hline Nomenclature & \\
ARF & area $\left(m^{2}\right)$ \\
$\Delta G^{\circ}$ & capital recovery factor \\
E & Gibbs free energy for reaction \\
EER & voltage $(\mathrm{V})$ \\
ERC & ejergy efficiency ratio \\
F & Faraday constant \\
ex & specific exergy rate $(\mathrm{kJ} / \mathrm{kg})$ \\
$\dot{E} x$ & exergy rate $(\mathrm{kW})$ \\
Geo & geothermal \\
h & enthalpy $(\mathrm{kJ} / \mathrm{kg})$ \\
$\mathrm{H}$ & Heat capacity \\
\hline
\end{tabular}




\begin{tabular}{|ll|}
\hline HHV & higher heating value \\
HT & high temperature \\
$i$ & current density, interest rate \\
$i_{L}$ & limiting current density. \\
K & specific heat capacity \\
$l_{m}$ & the membrane thickness \\
LMTD & logarithmic meant temperature difference \\
LT & low temperature \\
$\dot{m}$ & mass flow rate (kg/s) \\
$\dot{n}$ & Molar rate (mol/s) \\
ORC & organic Rankine cycle \\
ORFC & organic Rankine flash cycle \\
P & pressure (kPa) \\
PEM & polymer electrolyte membrane \\
$\dot{Q}_{c h e m}$ & Chemical energy \\
$\dot{Q}_{\text {sens,laten }}$ & sensible and latent heat \\
R & universal gas constant \\
$r_{m}$ & membrane resistivity \\
s & specific entropy (kJ/kg.K) \\
$S_{c e l l}$ & cell surface area \\
TEARS & triple effect absorption refrigeration \\
$\dot{W}$ & Power (kW) \\
x & molar fraction \\
subscript and & superscript \\
\hline
\end{tabular}




\begin{tabular}{|c|c|}
\hline activa & activation \\
\hline chem & chemical \\
\hline concen & concentration \\
\hline cond & condenser \\
\hline d & destruction \\
\hline el & electron \\
\hline eva & evaporator \\
\hline $\mathrm{FC}$ & fuel cell \\
\hline $\mathrm{f}$ & fuel cell, fuel \\
\hline in, $\mathrm{i}$ & inlet \\
\hline int & internal \\
\hline laten & latent \\
\hline out, e & outlet \\
\hline op\&mc & operation and maintenance \\
\hline PEC & purchase equipment cost \\
\hline sat & saturation \\
\hline sens & sensible \\
\hline tur & turbine \\
\hline $\mathrm{V}$ & vaporization \\
\hline$\circ$ & reference state \\
\hline
\end{tabular}

\section{Introduction}

Energy is one of the significant players of most of the activities and play an important role in the human society's development and the comfort of humankind. Due to the limited nature of fossil fuels, the substitution of this kind of fuel with other types is necessary [1]. Renewable energies as an alternative for common fossil fuels can partly compensate many problems associated with the 
use of these fuels. One of the renewable energy sources with several benefits such as safety, flexibility, simplicity, and easily combined with other energy systems, is geothermal energy [2]. Geothermal energy is available in the lower layers of the earth. Due to the contact of water with these hot shells and the advent of this hot water to the earth surface, it can be used for various purposes such as power generation, direct heating, and other heating applications [3].

The use of geothermal energy for direct heating or electricity generation purposes strongly depends on the temperature. Usually geothermal sources with high temperature around $150{ }^{\circ} \mathrm{C}$ is used to produce electrical energy. At the temperatures ranging from $90{ }^{\circ} \mathrm{C}$ to $150{ }^{\circ} \mathrm{C}$ or lower temperatures, i.e. below $50^{\circ} \mathrm{C}$, it is more suitable for direct heating [4]. Since the geothermal energy systems work at a low temperature, their efficiency are low this is why most applications are used to integrate this energy with other source of energies [5].

Ganjehsarabi H. [6] studied the possibility of utilizing low temperature heat source to produce electrical power. An organic Rankine cycle integrated with proton exchange membrane (PEM) electrolyzer driven by geothermal energy was analyzed. He used a mixture of butane, pentane, and iso-pentane was selected as working fluid. It was reported that using mixed working fluid enhance the system performance.

Karapekmez A. and Dincer I. [7] developed a novel solar and geothermal based integrated system to generate multi outputs. The energy and exergy efficiencies of system was reported $78.37 \%$ and $58.4 \%$ in the storing period, respectively.

Yilmaz C. [8] conducted a thermo-economic optimization on an alkaline water electorlyzer system driven by a combined flash binary geothermal power plant. They used genetic algorithm (GA) to minimize the exergetic cost of the system with respect to some practical constraints and design 
variables. The results demonstrated that the optimal values of product cost flow rate, fuel cost flow rate, electricity unit cost, hydrogen unit cost were around $2412 \$ / \mathrm{h}, 289.4 \$ / \mathrm{h}, 0.0107 \$ / \mathrm{kWh}$, and $1.088 \$ / \mathrm{kg}$, respectively while the corresponding values for the basic design obtained as $2607 \$ / \mathrm{h}$, $295.9 \$ / \mathrm{h}, 0.01105 \$ / \mathrm{kWh}$, and $1.149 \$ / \mathrm{kg}$, respectively.

Akrami E. et al. [9] developed a geothermal derive system consisting of an absorption refrigeration system, an organic Rankine cycle (ORC), a domestic hot water (DHW), and a polymer electrolyte membrane (PEM) electrolyzer. They assessed the effects of various important parameters on the performance of the system. Based on their outputs the energy and exergy efficiencies obtained as $34.98 \%$ and $49.17 \%$, respectively. Moreover, the highest and lowest total cost rate were 23.18 $\$ / G J$ and $22.73 \$ / G J$, respectively for increasing the geothermal source temperature from $185^{\circ} \mathrm{C}$ to $215^{\circ} \mathrm{C}$.

An integrated system to produce hydrogen by geothermal power unit as energy source was investigated by Yuksel Y.E. et al. [10]. After evaluation the effects of important parameters on the performance of the system, their results revealed that the energetic and exergetic efficiency reached $39.46 \%$ and $44.27 \%$ respectively. Additionally, it was concluded that an increase in the geothermal source temperature and an increase in the ambient temperature can enhance the system performance while increasing the pinch point temperature and turbine inlet pressure resulted in declining in the efficiency of the studied system.

In another work Yuksel Y.E. et al. [11] analyzed a novel geothermal integrated energy system. The studied system comprised of a geothermal system, a Kalina cycle, a single effect $\mathrm{Li} / \mathrm{Br}$ water absorption cooling system, a hydrogen production unit, and a storage unit. It was reported that the energetic and exergetic efficiency of the multi-generation energy system reached up to $42.59 \%$ 
and $48.24 \%$, respectively. Their results also showed that the integrated energy system for multigeneration has several benefits such as the higher efficiency and lower emissions.

Exergy and exergo-economic analyses for a cogeneration system producing fresh water and hydrogen was conducted by Kianfard et al. [12]. The proposed system comprised of a geothermal based organic Rankine cycle (ORC), a PEM electrolyzer, and a reverse osmosis desalination unit (RO). The evaluations demonstrated that the highest exergy destruction rate belonged to ORC, which was $59 \%$ of total exrgy destruction rate of the system. In addition, an increase in the geothermal water temperature led to a reduction in the overall exergy efficiency. The exergoeconmic analysis indicated that the exergy cost of geothermal hot water, the produced hydrogen, and distilled water were about $1.3 \$ / \mathrm{GJ}, 4.257 \$ / \mathrm{kg}$, and $32.73 \mathrm{cent} / \mathrm{m}^{3}$, respectively.

Yilmaz C. and Kanoglu M. [13] performed a thermodynamic analysis of a PEM water electrolyzer driven by a geothermal source for hydrogen production. They applied both energy and exergy analyses to the integrated system. They have also conducted a comprehensive parametric study of the variation of geothermal resource temperature and mass flow rate of the geothermal water. The energy and exergy efficiencies of geothermal power generation unit were $11.4 \%$ and $45.1 \%$, respectively. In addition, corresponding values for electrolyzer unit and overall system were $64 \%$, $61.6 \%$, as well as $6.7 \%, 23.8 \%$, respectively.

Ebadolahi M. et al. [14] proposed a novel geothermal-based system to produce some beneficial outputs including heating, cooling, power, and hydrogen simultaneously beside liquefied natural gas (LNG) as cold energy recovery. The overall system composed of some subsystems including an organic Rankine cycle (ORC), an ejector refrigeration cycle (ERC), an LNG power system, and a proton exchange membrane electrolyzer (PEM) system. The results revealed that the proposed system could provide cooling capacity, heating capacity, net output power, and hydrogen of 1020 
$\mathrm{kW}, 334.8 \mathrm{~kW}, 1060 \mathrm{~kW}, 5.43 \mathrm{~kg} / \mathrm{h}$, respectively. Furthermore, the energy and exergy efficiencies and the total unit cost of products were $38.33 \%, 28.91 \%$, and 347.9 \$ GJ respectively. Further studies on the geothermal energy with different energy systems can be found in Refs. [15-17] . In addition to geothermal energy, fuel cells are an interesting kind of power generation devices that are used in a wide range of applications such as transportation and power generation units in fixed plants and portable units. The wide range of output power from $\mathrm{mW}$ to MW of these systems has made them more flexible [18]. However, this type of equipment has theoretical efficiency of about $70 \%$, and in practice, their efficiency is in the range of $45 \%-60 \%$. The byproducts of such equipment is water, heat, and electricity [4]. One of the fuel cell types, which can be used for various applications, is proton exchange membrane (PEM) fuel cell that has higher energy density and rapid start up. The operating temperature of PEM fuel cell is less than $100^{\circ} \mathrm{C}$, which makes them attractive for domestic applications [19].

Fuel cells have unique potentials to integrate with other energy systems. Hence, one of the unique and promising integrations for increasing efficiency is the combination of geothermal energy systems with fuel cell systems. The smart design of these systems in the combination with thermodynamic cycle can improve the overall system performance.

An experimental study on a hybrid energy system including a proton exchange membrane fuel cell (PEMFC) unit whose hydrogen was provided by a fuel reforming process was considered by Bendaikha et al. [20]. The wasted heat of PEMFC was utilized in a thermal storage tank mixed with geothermal water. A part of the hot water utilized in a fan coil for space heating and cooling demand, a subsystem consisting of a heat pump, fan coil, and cool water tank employed. According to the results, the $\mathrm{COP}$ of heating mode was 3.34 also the $\mathrm{COP}_{\text {sys }}$, and the energy efficiency ratio 
(EER) of cooling mode obtained as 2.49 and 11.5 respectively. Moreover, the PEMFC efficiency were $45 \%$ and $68 \%$ for heating and cooling mode, respectively.

Ratlamwala T.A.H et al. [21] considered an integrated PEMFC and triple effect absorption refrigeration (TEARS) and geothermal system to provide cooling/heating and power demand for a building. They combined a PEMFC and a triple effect absorption chiller with geothermal energy sources to meet these demands. The analysis was carried out to show the effect of different operating conditions on the main output parameters of the suggested system. Their results indicated that with increasing the temperature of the fuel cell, the efficiency, the utilization factor and the change in the temperature of hot water increase from $36 \%$ to $48.8 \%$, and $49 \%$ to $86 \%$ and $14 \mathrm{~K}$ to $23 \mathrm{~K}$, respectively.

Al-Nimr M. et al. [22] investigated the behavior of a solar powered organic Rankine cycle with geothermal cooling and electrolyzer/fuel cell storage system. It is reported that increasing the effectiveness of the condensation stage in the geothermal heat exchanger enhance the required NTU and decrease the required flow rate.

In a research study, Sigurvinsson J. et.al [23] tried to reduce the energy required for water elecrolysis using the geothermal energy. A techno-economic optimization model was developed to model and optimize the electrolyzer and the high temperature heat exchanger network. It was reported that using the geothermal source temperature as low as $230^{\circ} \mathrm{C}$; the high temperature electrolyzer could compete with alkaline electrolyzers.

Frazzica A. et al. [24] developed a combined system includes a heat pump and a fuel cell to reduce the energy consumption of buildings. Three different heat pump technologies were analyzed. It was claimed that the overall yearly efficiency could be increase about $30 \%$, by exploiting the heat released by the micro CHP to decrease the generated heat by the heat pump. 
Yilmaz C. et al. [25] studied a geothermal energy system based on artificial neural network to produce hydrogen. A geothermal source with $100 \mathrm{~kg} / \mathrm{s}$ flow rate and $200{ }^{\circ} \mathrm{C}$ was used for electricity generation and water electrolysis. It was reported that the overall exergy efficiency of system, the unit cost of produced hydrogen and simple payback period of system are $38.37 \%$,

\section{$1.088 \$ / \mathrm{kg} \mathrm{H}_{2}$ and 4.074 years, respectively.}

As the literature review shows, various hybrid geothermal energy systems have been investigated.

Due to the temperature range of the geothermal energy as well as the rejected heat occurring in the fuel cell and its operating temperature, suitable hybrid systems can be designed with better efficiency using the geothermal energy and fuel cells. A review of the work conducted shows that although this combination has good potentials, there is still little research in this regard from their integration, assessment, and multi-objective optimization.

In the current research, our main goal is to integrate a PEM fuel cell with a geothermal source and compare the suggested systems. Hence, the simulation and thermodynamic modeling as well as the economic analysis of the hybrid geothermal and fuel cell system are carried out. In this regard, an organic Rankine flash cycle is employed to extract geothermal energy. Additionally the possibility of replacement of the low temperature geothermal source with fuel cell rejected heat is studied. To assess the thermodynamics and economics of the suggested systems, thermodynamic analyses and exergo-economic analysis along with an evolutionary based multi-objective optimization have been performed on the novel integrated system and the results are compared. In addition, to determine the optimal design parameters of the integrated system Pareto curve is obtained from the optimization study.

\section{Systems layout}


Fig. 1 shows the schematic of the integrated energy systems. Fig. 1(a) represents a geothermal based organic Rankine flash cycle (Geo/ORFC) that uses a high-temperature source with $130{ }^{\circ} \mathrm{C}$ and low-temperature geothermal source with $95{ }^{\circ} \mathrm{C}$ for the system start up. A flash vessel is also employed to have a better control on the cycle. Hence, this system in known as organi Rankine flash cycle ()ORFC). Since the fuel cell operating temperature is in the range of 80 to $90{ }^{\circ} \mathrm{C}$, its integration with the geothermal system can improve the system performance. Therefore, in the geothermal Organic Rankine flash cycle and fuel cell (Geo/ORC-FC) system, the fuel cell rejected heat is used instead of the low-temperature geothermal heat source (Fig. 1(b)). Both systems use two turbines to generate electrical energy. More detail about system components can be seen in Fig. 1(a) and Fig. 1(b). As it is seen in Fig. 1(a) the working fluid after passing through evaporator I, enters a throttle valve which pressure reduces in a constant enthalpy. Then in the flash vessel, the vapor and liquid are separated which vapor guides to the turbine inlet to generate power and liquid part converts to the saturated vapor in the evaporator II and produces more work in turbine II. In the turbines outlet the steam after passing through condenser I and condenser II, they pump to an appropriate level, mixed and the cycle is closed. 


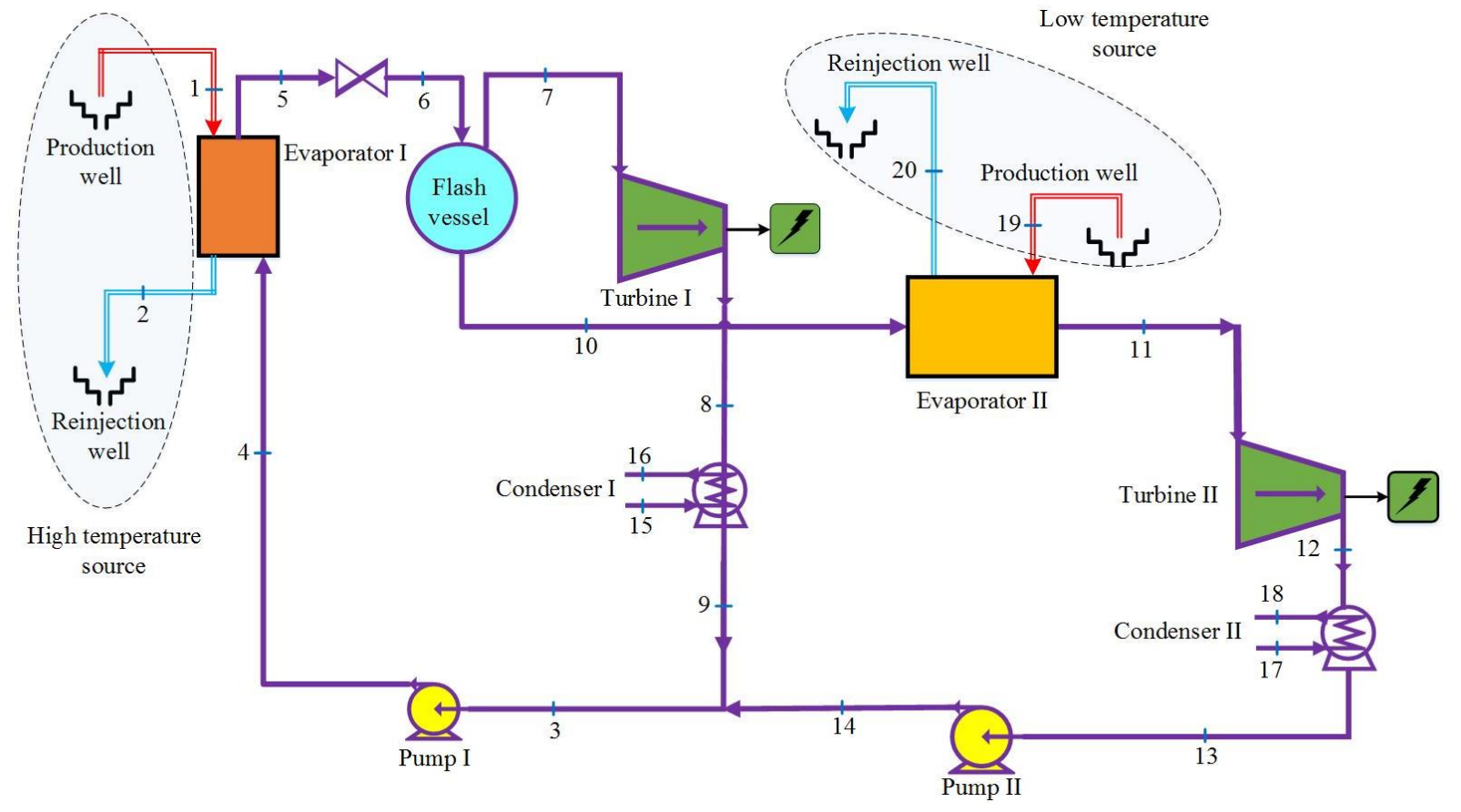

(a)

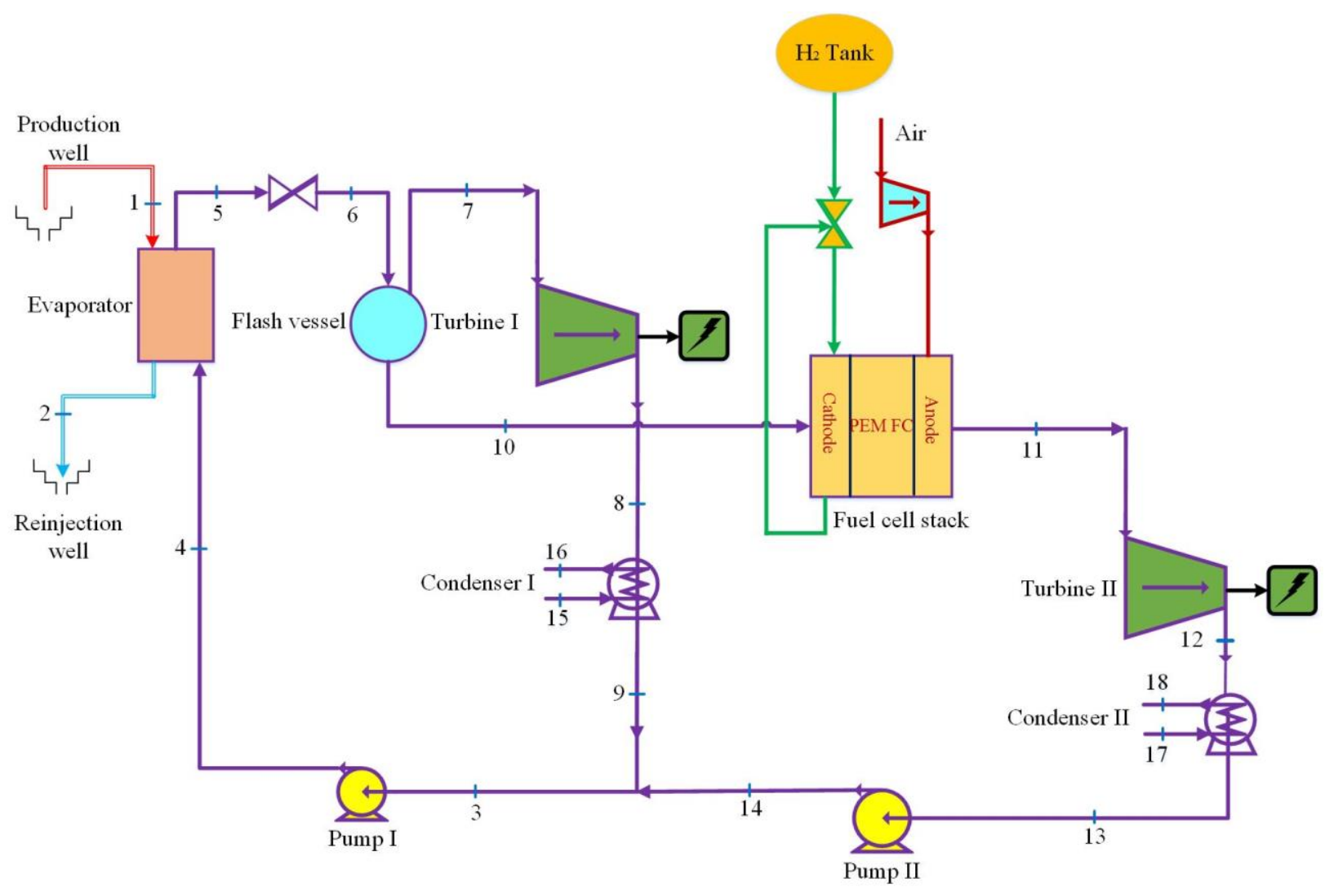

(b) 
Fig. 1 Schematic diagram of suggested systems (a) Geo/ORFC system (b) Geo/ORFC-FC system

\section{Mathematical model and performance criteria}

The simulation of the studied systems in the present work includes the thermodynamic modeling of the entire system with all subsystems and the extraction of an economic model to obtain the cost of each component necessary for economic analysis. Here, all the components are considered as a control volume in steady state condition.

\subsection{Thermodynamic modeling}

For thermodynamic modeling of systems, the conservation of mass and energy are applied. To simplify the mathematical model some assumption are made [26]:

- All process under consideration are steady state.

- The heat loss in components and pressure drop along the devices is neglected.

- Isentropic efficiency of both pumps and both turbines are assumed $85 \%$ and $87 \%$.

- The inlet temperature and pressure of the condenser-cooling stream are considered as the ambient temperature and pressure.

As described in Fig. 1, the overall Geo/ORFC includes two evaporators, two turbines, two pumps, two condensers and low and high temperature geothermal sources. According to the abovementioned assumptions, the governing equations for each component as a control volume can be expressed as follows.

For Geo/ORFC configuration, the governing equations of both evaporators are as:

$$
\dot{m}_{1}\left(h_{1}-h_{2}\right)=\dot{m}_{4}\left(h_{5}-h_{4}\right)
$$




$$
\dot{m}_{19}\left(h_{19}-h_{20}\right)=\dot{m}_{10}\left(h_{11}-h_{10}\right)
$$

The expansion valve and flash vessel governing equation are

$$
\dot{m}_{6} h_{6}=\dot{m}_{7} h_{7}+\dot{m}_{10} h_{10}
$$

For both turbines, the mas and energy equation are given by:

$$
\begin{aligned}
& W_{\text {tur-I }}=\dot{m}_{7}\left(h_{7}-h_{8}\right) \\
& \eta_{\text {is }, \text { tur }-I}=\frac{h_{7}-h_{8}}{h_{7}-h_{8 s}} \\
& W_{\text {tur-II }}=\dot{m}_{11}\left(h_{11}-h_{12}\right) \\
& \eta_{\text {is,tur-II }}=\frac{h_{11}-h_{12}}{h_{11}-h_{12 s}}
\end{aligned}
$$

Here, $h_{8 s}, h_{12 s}$ denote the turbines outlet enthalpy where turbines expansion are isentropic.

For both condensers and pumps, the governing equations are as:

$$
\begin{aligned}
& \dot{m}_{8}\left(h_{8}-h_{9}\right)=\dot{m}_{15}\left(h_{16}-h_{15}\right) \\
& \dot{m}_{12}\left(h_{12}-h_{13}\right)=\dot{m}_{17}\left(h_{18}-h_{17}\right)
\end{aligned}
$$

\subsection{Polymer electrolyte membrane fuel cell}

In this section, the thermodynamic simulation of PEM-FC is presented. To simplify the analysis of PEM-FC, some assumption are made as follow [26]:

- The system operates under the steady states conditions.

- The pressure drop in PEM-FC is negligible.

- The fuel cell operation temperature is $85^{\circ} \mathrm{C}$.

- The composition of air in the fuel cell is considered $79 \% \mathrm{~N}_{2}$ and $21 \% \mathrm{O}_{2}$.

- There is not heat losses to environment. 
In a PEM-FC stack, hydrogen and oxygen (air) are supplied to the electrodes to generate water, heat, and electricity. The chemical reaction in such system can be expressed as:

Anode reaction $: \mathrm{H}_{2} \rightarrow 2 \mathrm{H}^{+}+2 e^{-}$

Cathode reaction: $2 \mathrm{H}^{+}+2 e^{-}+\frac{1}{2} \mathrm{O}_{2} \rightarrow \mathrm{H}_{2} \mathrm{O}+$ thermal energy

Total reaction: $\mathrm{H}_{2}+\frac{1}{2} \mathrm{O}_{2} \longrightarrow \mathrm{H}_{2} \mathrm{O}$

From the well-known Nernst relation, the reversible open voltage form hydrogen-oxygen reaction can be obtained as follow:

$$
E_{\text {Nernst }}=\frac{-\Delta G^{\circ}}{n_{e l} F} \frac{R T_{f}}{N_{e l} F} \ln (Q)
$$

Where $\Delta G^{\circ}$ denotes the Gibbs free energy for reaction, $N_{e l}$ is number of electrons which transfer in the chemical reaction, $F$ represents the faraday constant, $\mathrm{R}$ is universal constant of gas, and $T_{f}$ is the operating temperature of PEM-FC in Kelvin and $Q$ is the quotient of equation and it can be calculated as:

$$
Q=\frac{P_{H_{2}} \sqrt{P_{O_{2}}}}{P_{H_{2} O}^{s a t}}
$$

Where all $\mathrm{P}$ value in the above equation denote the effective partial pressure of each reactant. The water vapor saturation pressure can be computed from the following empirical relation:

$$
\begin{aligned}
& \log _{10}\left(P_{H_{2} O}^{s a t}\right)=-2.1794+0.02253\left(T_{f}-273.15\right)-\left(9.183-10^{-5}\right) \times\left(T_{f}-\right. \\
& 273.15)^{2}+\left(1.4554 \times 10^{-7}\right)\left(T_{f}-273.15\right)^{3}
\end{aligned}
$$

The effective partial pressure of $P_{H_{2}}$ and $P_{O_{2}}$ at anode and cathode are similar all over the cell and can be computed as: 


$$
\begin{aligned}
& P_{H_{2}}=\left(\frac{1}{2} P_{H_{2} O}^{s a t}\right)\left[\frac{1}{\exp \left(\frac{1.653 i}{T_{f c}^{1.334}}\right) \cdot x_{H_{2} O}^{s a t}}-1\right] \\
& P_{O_{2}}=P\left[\frac{1}{\exp \left(\frac{1.653 i}{\left.T_{f c}^{1.334}\right) \cdot x_{H_{2} O}^{s a t}}-1-x_{H_{2} O}^{s a t}-x_{N_{2}}^{\text {channel }} \exp \left(\frac{0.291 i}{T_{f}^{0.832}}\right)\right]}\right.
\end{aligned}
$$

Where the above equation parameters are:

$x_{\mathrm{H}_{2} \mathrm{O}}^{\mathrm{sat}}$ : Molar fraction of the water in a gas flow at saturation for the given temperature

$x_{\text {other gases }}^{\text {channel }}$ : The molar fraction of other gases in airflow except oxygen

$i$ : Current density

$x_{N_{2}}^{\text {channel }}$ : Molar fraction of nitrogen

The abovementioned parameters can be calculated as the follow [27]:

$$
\begin{aligned}
& x_{H_{2} O}^{\text {sat }}=\frac{P_{H_{2} O}^{\text {sat }}}{P} \\
& x_{N_{2}}^{\text {channel }}=\frac{\left(x_{N_{2}, \text { in }}-x_{N_{2}, \text { out }}\right)}{\ln \left(\frac{x_{N_{2}, \text { in }}}{x_{N_{2}, \text { out }}}\right)} \\
& x_{N_{2}, \text { in }}=0.79\left(1-x_{H_{2} O}^{\text {sat }}\right) \\
& x_{N_{2}, \text { out }}=\frac{1-x_{H_{2} O}^{\text {sat }}}{1+\left(\left(\lambda_{\text {air }}-1\right) / \lambda_{\text {air }}\right)\left(\frac{0.21}{0.79}\right)}
\end{aligned}
$$

Here $x_{N_{2}, \text { in }}$ and $x_{N_{2} \text {,out }}$ represent the molar fraction of nitrogen in inlet and outlet, respectively. $\lambda_{\text {air }}$ show the stoichiometric rate of air.

Generally, the real measured voltage in PEM-FC is smaller than the theoretical (the reversible voltage) form Nernst relation because of some losses that occur such as the activation over- 
potential, ohmic over-potential, and concentration potential. All these effects should be considered to calculate the actual voltage, which can be written as follow:

$$
V_{f}=E_{\text {Nernst }}-\xi_{\text {activa }}-\xi_{\text {ohmic }}-\xi_{\text {concen }}
$$

Here $\xi_{\text {active }}, \xi_{\text {ohmic }}$ and $\xi_{\text {concen }}$ are the activation, Ohmic and concentration over-potential, respectively. A semi-empirical relation for the activation over-potential can be expressed as [28]:

$$
\xi_{\text {active }}=\alpha_{1}+\alpha_{1} T+\alpha_{3} T \ln \left(C_{O_{2}}\right)+\alpha_{4} T \ln \left(i S_{\text {cell }}\right)
$$

Here $S_{\text {cell }}$ is cell surface area and $\alpha_{j}$ are that can be expressed as:

$\alpha_{1}=-0.948, \alpha_{2}=0.00286+0.0002 \ln \left(S_{\text {cell }}\right)+0.000043 \times \ln \left(C_{H_{2}}\right), \alpha_{3}=0.000076, \alpha_{4}=$ $-0.000193$

The hydrogen in anode-membrane surface $\left(C_{O_{2}}\right)$ and oxygen concentration in cathode-membrane $\left(C_{H_{2}}\right)$ can be specified by Henry's law as follows:

$$
\begin{aligned}
C_{H_{2}} & =9.174 \times 10^{-7} P_{H_{2}} \exp \left(-\frac{77}{T}\right) \\
C_{O_{2}} & =1.97 \times 10^{-7}\left(\frac{498}{T}\right)
\end{aligned}
$$

The Ohmic over-potential based on Ohm's Law is as:

$$
\xi_{\text {ohmic }}=i R^{\text {int }}
$$

Where, $R^{\text {int }}$ is internal resistance which can be calculated from the following equation including all membrane variables:

$$
R^{i n t}=\frac{r_{m} l_{m}}{S_{c e l l}}
$$

$S_{m}$ shows the cell area, $l_{m}$ represents the membrane thickness, and $r_{m}$ is membrane resistivity which can be calculated from an empirical relation as: 


$$
r_{m}=\frac{181.6\left[1+0.03(i)+0.062\left(\frac{i . S_{\text {cell }}}{303}\right)^{2}(i)^{2.5}\right]}{\left[11.866+3(i) \exp \left(4.18\left(\frac{T-303}{T}\right)\right)\right]}
$$

The concentration over-potential is because of the concentration gradient between reactants and products at the electrode surface and the bulk solution. It can be calculated as:

$$
\xi_{\text {concen }}=\frac{R T_{f}}{n_{e} F}\left(\frac{i_{L}}{i_{L}-i}\right)
$$

Here, $i_{L}$ is the limiting current density.

In addition, the generated power by the PEM-FC stack can be calculated as:

$$
W_{f}=N_{\text {cell }} V_{f} I
$$

Where $N_{\text {cell }}$ represent the number of cell in stack.

The energy balance for the whole of PEM-FC can be written as follows:

$$
\dot{Q}_{n e t}=\dot{Q}_{\text {chem }}-\dot{W}_{f}-\dot{Q}_{\text {sens,laten }}
$$

Where $\dot{Q}_{c h e m}$ and $\dot{Q}_{\text {sens,laten }}$ are chemical energy and sensible and latent heat and $\dot{W}_{f}$ presents the PEM-FC power output. In a fuel cell, the oxygen consumption rate, the hydrogen consumption rate and water production rate can be computed using the following relationships:

$$
\begin{aligned}
& \dot{n}_{H_{2}, \text { consum }}=N_{\text {cell }} \frac{I}{2 F} \\
& \dot{n}_{O_{2, \text { consum }}}=N_{\text {cell }} \frac{I}{4 F} \\
& \dot{n}_{H_{2} O, \text { produc }}=N_{\text {cell }} \frac{I}{2 F}
\end{aligned}
$$

The reactant molar flow rate can be calculated as follows:

$$
\dot{n}_{H_{2}}=\lambda_{H_{2}} \dot{n}_{H_{2}, \text { consum }}=\lambda_{H_{2}} N_{\text {cell }} \frac{I}{2 F}
$$




$$
\dot{n}_{O_{2}}=\lambda_{H_{2}} \dot{n}_{O_{2}, \text { consum }}=\lambda_{O_{2}} N_{\text {cell }} \frac{I}{2 F}
$$

Concerning the input hydrogen rate and about the above relations, the air intake can be achieved. The theoretical work rate released from the electrochemical reaction is obtained from the following equation:

$$
\dot{Q}_{\text {chem }}=\dot{n}_{\mathrm{H}_{2}, \text { consum }} \cdot \mathrm{HHV}
$$

Here HHV represents the higher heating value of hydrogen. Additionally, to calculate the latent heat and sensible heat the following equation can be employed:

$$
\begin{aligned}
\dot{Q}_{\text {sens,laten }}= & K_{H_{2}}\left(\dot{n}_{H_{2}, \text { out }} T_{f}-\dot{n}_{H_{2}, \text { in }} T_{\text {amb }}\right)+K_{O_{2}}\left(\dot{n}_{O_{2}, \text { out }} T_{f}-\dot{n}_{O_{2}, \text { in }} T_{\text {out }, \text { comp }}\right) \\
& +K_{N_{2}}\left(\dot{n}_{N_{2}, \text { out }} T_{f}-\dot{n}_{N_{2}, \text { in }} T_{\text {out }, \text { comp }}\right) \\
& +\dot{n}_{H_{2} \text { O,produce }}\left(T_{f}-T_{\text {amb }}\right) K_{H_{2} O}+\dot{n}_{H_{2} \text { O,produce }} H_{v}
\end{aligned}
$$

Where $K_{\mathrm{H}_{2}}, K_{\mathrm{O}_{2}}, K_{\mathrm{N}_{2}}$ and $K_{\mathrm{H}_{2} \mathrm{O}}$ are specific heat capacity of hydrogen, nitrogen, and water, respectively. $H_{v}$ is the vaporization heat capacity of water.

More details about PEM-FC are described in Appendix.

\subsection{Exergy analysis}

Exergy analysis is a powerful tool to evaluate energy systems. Based on the definition, exergy is the maximum useful work that can be extracted from streams to reach environmental conditions. In this case, the value of maximum work obtainable during the process from the initial state to the environmental state known as exergy. To precisely evaluate energy systems many exergy parameters can be defined.

Exergy efficiency and exergy destruction rate are two significant parameters in examining different energy systems. Both of these parameters play an important role in identifying inefficient 
points in the system. Using the following equations, one can obtain the exergy of each point of the system with its thermodynamic properties.

$$
e x=e x_{\text {phys }}+e x_{\text {chem }}+e x_{\text {poten }}+e x_{\text {kinet }}
$$

Eq. (47) represents the four main components of the exergy of flow. Here ex $x_{\text {phys }}$, ex $x_{c h e m}$, ex $x_{\text {poten }}$ and $e x_{\text {kinet }}$ indicate the physical, chemical, potential and kinetic exergy . Physical physical exergy can be achieved by the following equation:

$$
\text { ex } x_{\text {phys }}=\left(h-h_{\circ}\right)-T_{\circ}\left(s-s_{\circ}\right)
$$

In many applications the change in potential and kinetics exergy are neglected [29,30]. Chemical exergy is not considered unless chemical reactions or chemical composition difference occur. Using an empirical coefficient and higher heating value, the chemical exergy of various fuels, such as hydrocarbons and hydrogen fuels can be obtained from the following equation [31]:

$$
\varphi=\frac{e x_{f}}{L H V}
$$

The $\varphi$ values for some fuels are given in Ref. [32]. This value for hydrocarbon fuels is between 1.04 and 1.08. For hydrogen used here as main fuel of the PEM-FC, the value of $\varphi$ is 0.985 [32]. The general exergy balance for each component considered as a control volume at steady state can be presented as follows [33]:

$$
\dot{E} x_{Q}+\sum_{i} \dot{m}_{i} e x_{i}=\sum_{e} \dot{m}_{e} e x_{e}+\dot{E} x_{w}+\dot{E} x_{\text {destruction }}
$$

Here $\dot{E} x_{Q}, \dot{E} x_{w}$ and $\dot{E} x_{\text {destruction }}$ are associated to exergy of heat transfer, exergy of work and exergy destruction rate of the control volume to which exergy balance applied.

Table 1 shows the equations for exergy efficiency and exergy destruction rate for each component of the studied systems. 
Table 1. Exergy destruction rate and exergy efficiency of each component of Geo/ORFC and Geo/ORFC-

FC systems [34,35]

\begin{tabular}{|c|c|c|}
\hline Component & Exergy destruction rate expression & Exergy efficiency expression \\
\hline Evaporator I & $\dot{E} x_{d, e v a-I}=\dot{E} x_{1}-\dot{E} x_{2}+\dot{E} x_{4}-\dot{E} x_{5}$ & $\frac{\dot{E} x_{1}-\dot{E} x_{2}}{\dot{E} x_{5}-\dot{E} x_{4}}$ \\
\hline Turbine I & $\dot{E} x_{d, t u r-I}=\dot{E} x_{7}-\dot{E} x_{8}-\dot{W}_{t u r-I}$ & $\frac{\dot{W}_{t u r-I}}{\dot{E} x_{7}-\dot{E} x_{8}}$ \\
\hline Condenser I & $\dot{E} x_{d, \text { cond }-I}=\dot{E} x_{8}-\dot{E} x_{9}+\dot{E} x_{15}-\dot{E} x_{16}$ & $\frac{\dot{E} x_{16}-\dot{E} x_{15}}{\dot{E} x_{8}-\dot{E} x_{9}}$ \\
\hline Pump I & $\dot{E} x_{d, p u m p-I}=\dot{E} x_{4}-\dot{E} x_{3}+\dot{W}_{\text {pump-I }}$ & $\frac{\dot{E} x_{4}-\dot{E} x_{3}}{\dot{W}_{\text {pump-I }}}$ \\
\hline Evaporator II & $\dot{E} x_{d, e v a-I I}=\dot{E} x_{10}-\dot{E} x_{11}+\dot{E} x_{19}-\dot{E} x_{20}$ & $\frac{\dot{E} x_{11}-\dot{E} x_{10}}{\dot{E} x_{19}-\dot{E} x_{20}}$ \\
\hline Turbine II & $\dot{E} x_{d, t u r-I I}=\dot{E} x_{11}-\dot{E} x_{12}-\dot{W}_{t u r-I I}$ & $\frac{\dot{W}_{t u r-I I}}{\dot{E} x_{11}-\dot{E} x_{12}}$ \\
\hline Condenser II & $\dot{E} x_{d, \text { cond }-I I}=\dot{E} x_{11}-\dot{E} x_{12}-\dot{W}_{t u r-I I}$ & $\frac{\dot{E} x_{18}-\dot{E} x_{17}}{\dot{E} x_{12}-\dot{E} x_{13}}$ \\
\hline Pump II & $\dot{E} x_{d, p u m p-I I}=\dot{E} x_{12}-\dot{E} x_{13}+\dot{E} x_{17}-\dot{E} x_{18}$ & $\frac{\dot{E} x_{14}-\dot{E} x_{13}}{\dot{W}_{\text {pump-II }}}$ \\
\hline PEM-FC & $\dot{E} x_{d, P E M-F C}=\dot{E} x_{10}-\dot{E} x_{11}+\dot{E} x_{H_{2}}-\dot{W}_{f}$ & $\frac{\dot{E} x_{10}-\dot{E} x_{11}-\dot{W}_{f}}{\dot{E} x_{H_{2}}}$ \\
\hline
\end{tabular}

\subsection{Economic analysis}

This section deals with the economic modeling of the studied systems in order to obtain the cost of each part and consequently the total cost rate of the proposed systems. The cost function of components in terms of operating parameters, which is a measure of the system size, can be 
employed to determine the system component cost. Table A.1 in Appendix shows the purchase cost of each components of Geo/ORFC and Geo/ORFC-FC systems.

The total cost of each element is the sum of costs associated with the purchasing and the maintenance cost. In order to obtain the total cost of each part, the two costs must be added. Thus, the cost of component $k$ can be expressed as the following [36]:

$$
Z_{k}=Z_{P E C}+Z_{o p \& m c}
$$

Where $Z_{P E C}$ and $Z_{o p \& m c}$ are the purchase equipment cost and operation and maintenance cost of component $k$, respectively.

The cost rate of system is employed in which uses economic parameters such as Capital Recovery Factor $(C R F)$ and interest rate $(i)$ and it can can better evaluate the system cost. Here the cost rate of each component are obtained with use the following equations .

$$
\dot{Z}_{k}=\frac{Z_{k} \times C R F}{n}
$$

Where $n$ shows the number of system operation hours in a year that is 7000 hours in this study and $Z_{k}$ is the sum of operation and maintenance cost and purchase equipment cost. In addition, $C R F$ can be calculated from the following relation:

$$
C R F=\frac{i(1+i)^{y}}{(1+i)^{y}-1}
$$

Where $y$ is the number of year which the system in operation and $i$ represents the interest rate value.

\subsection{Systems description}

To evaluate the proposed systems, we need to define indicators that can properly demonstrate the systems performance. Since the aim of current study is thermo-economic analysis of the mentioned 
system, it is necessary to introduce indicators that measure the thermal and economic performance of the system.

The main indicators include the net output power and first and second law efficiency, which can be defined as:

$$
\begin{aligned}
& \dot{W}_{n e t, G e o-O R F C}=\dot{W}_{t u r-I}+\dot{W}_{t u r-I I}-\dot{W}_{\text {pump-I}}-\dot{W}_{\text {pump-II }} \\
& \dot{W}_{n e t, G e o-O R F C-F C}=\dot{W}_{t u r-I}+\dot{W}_{t u r-I I}-\dot{W}_{p u m p-I}-\dot{W}_{p u m p-I I}+\dot{W}_{f} \\
& \eta_{I, G e o / O R F C}=\frac{\dot{W}_{n e t, G e o / O R F C}}{\dot{Q}_{G e o, H T}+\dot{Q}_{G e o, L T}} \\
& \eta_{I, G e o / O R F C-F C}=\frac{\dot{W}_{n e t, G e o / O R F C-F C}}{\dot{Q}_{G e o, H T}+\dot{W}_{f}} \\
& \eta_{I I, G e o / O R F C}=\frac{\dot{W}_{n e t, G e o / O R F C-F C}}{\dot{E} x_{Q, G e o, H T}+\dot{E} x_{Q, G e o-L T}} \\
& \eta_{I I, G e o / O R F C-F C}=\frac{\dot{W}_{n e t, G e o / O R F C-F C}}{\dot{E x}_{Q_{G e o}, H T}+\dot{W}_{f}}
\end{aligned}
$$

Here $\dot{\mathrm{Q}}_{\mathrm{Geo} \_\mathrm{LT}}$ and $\dot{\mathrm{Q}}_{\mathrm{Geo} \_\mathrm{HT}}$ are the heat supplied to the ORFC working fluid by low temperature and high temperature sources, respectively. The values of high and low-temperature geo-fluid sources are as follow:

$$
\begin{gathered}
\dot{Q}_{G e o, L T}=\dot{m}_{19}\left(h_{19}-h_{18}\right) \\
\dot{Q}_{G e o, H T}=\dot{m}_{1}\left(h_{1}-h_{2}\right)
\end{gathered}
$$

Additionally the total cost rates of Geo/ORFC and Geo/ORFC-FC systems are other important indicators to evaluate the economic aspect of the studied systems and it can be expressed as follow: 


$$
\begin{aligned}
\dot{Z}_{G e o / O R F C}= & \dot{Z}_{\text {eva-I }}+\dot{Z}_{t u r-I}+\dot{Z}_{c o n d-I}+\dot{Z}_{\text {pump }-I}+\dot{Z}_{F V}+\dot{Z}_{E v a-I I}+\dot{Z}_{t u r-I I} \\
& +\dot{Z}_{c o n d-I I}+\dot{Z}_{\text {pump-II }} \\
\dot{Z}_{\text {Geo/ORFC-FC }} & \dot{Z}_{\text {eva-I }}+\dot{Z}_{t u r-I}+\dot{Z}_{c o n d-I}+\dot{Z}_{\text {pump-I}}+\dot{Z}_{F V}+\dot{Z}_{t u r-I I}+\dot{Z}_{c o n d-I I} \\
& +\dot{Z}_{\text {pump-II }}+\dot{Z}_{P E M-F C}
\end{aligned}
$$

\section{Results and discussion}

In this section, the results of the energy, exergy and economic analyses of the studied systems are presented. After the comparative analysis between two considered integrated systems, the results of the genetic algorithm based multi-criterion optimization of the selected system are described. Additionally, the results of the validation for subsystems of the simulated integrated system will provide.

\subsection{Validation}

With the aim of validating the developed modeling for the organic Rankine flash cycle, the data reported in literature is used [36,37]. The validation performed for the ORFC section in Geo/ORFC-FC configuration are presented in Table 2. The net output power of the cycle is considered as the validation goal and compared with results outlined by researches presented by Lee et al. [37] and Nemati et al. [38]. Regarding Table 2 good agreements are observed, between the obtained results in the present model and those reported in the literature.

Table 2. Comparison of main output of the Geo/ORFC-FC system with data in Refs. [37,38]

\begin{tabular}{|c|c|c|c|c|c|c|}
\hline Reference & $\begin{array}{c}\text { Working } \\
\text { fluid }\end{array}$ & $\begin{array}{c}\text { Evaporation } \\
\text { temperature } \\
{ }^{\circ} \mathrm{C}\end{array}$ & $\begin{array}{c}\text { Condensation } \\
\text { temperature } \\
{ }^{\circ} \mathrm{C}\end{array}$ & $\begin{array}{c}\text { Turbine I power } \\
\text { output calculated } \\
(\mathrm{kW})\end{array}$ & $\begin{array}{c}\text { Turbine output } \\
\text { power in reference } \\
(\mathrm{kW})\end{array}$ & Error \\
\hline
\end{tabular}




\begin{tabular}{|l|c|c|c|c|c|c|}
\hline \multirow{2}{*}{$\begin{array}{l}\text { Lee et al. } \\
\text { [37] }\end{array}$} & \multirow{2}{*}{ R245fa } & 80 & 40 & 24.46 & 24.89 & $1.76 \%$ \\
\cline { 3 - 7 } & 100 & 40 & 26.01 & 26.7 & $2.65 \%$ \\
\hline $\begin{array}{l}\text { Nemati et } \\
\text { al. [38] }\end{array}$ & \multirow{2}{*}{ o-xylen } & 80 & - & 24.89 & 24.76 & $-0.5 \%$ \\
\cline { 3 - 7 } & 100 & - & 26.7 & 26.2 & $-1.87 \%$ \\
\hline
\end{tabular}

In addition the PEM-FC model is validated with Ju and Wang experimental data [39] which is shown in Fig 2.

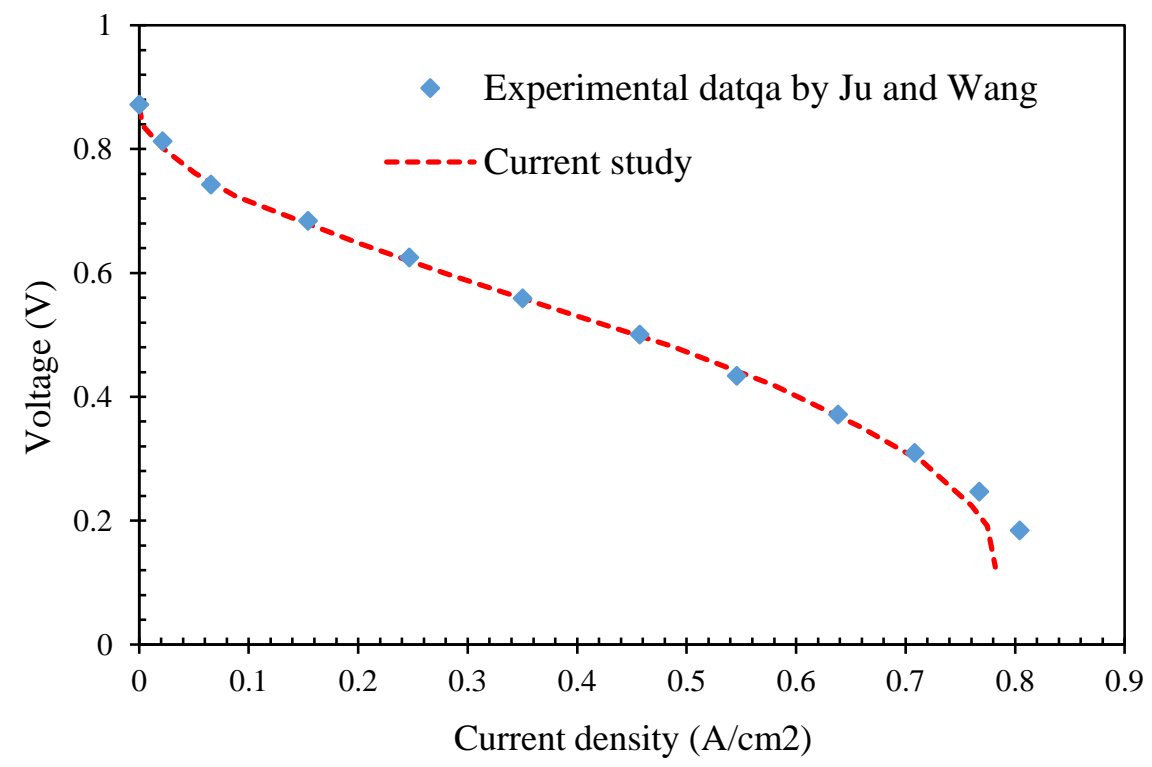

Fig. 2. The average polarization curves for cathode stoichiometry of 3.0 at $0.75 \frac{\mathrm{A}}{\mathrm{cm}^{2}}$.

The comparison between experimental data of Ju and Wang [39] with current model indicate a good consistency between outputs.

\subsection{Systems comparison}

Here two systems, which previously introduced, including the Geo/ORFC system and Geo/ORFCFC system are evaluated and analyzed. Due to the geothermal source temperature, a limited 
number of working fluid can be employed. The thermodynamic characteristics of selected working fluids are given in Table 3.

Table 3. Thermo-physical properties of employed organic fluids

\begin{tabular}{|c|c|c|c|c|c|}
\hline Working fluid & $\begin{array}{c}\text { Molecular weight } \\
(\mathrm{kg} / \mathrm{kmol})\end{array}$ & $\begin{array}{c}\text { Critical pressure } \\
(\mathrm{kPa})\end{array}$ & $\begin{array}{c}\text { Critical temperature } \\
(\mathrm{K})\end{array}$ & $\mathrm{GWP}^{\mathrm{a}}$ & ODP $^{\mathrm{b}}$ \\
\hline $\mathrm{R} 245 \mathrm{fa}$ & 134.05 & 3651 & 427.2 & 950 & 0 \\
\hline $\mathrm{R} 123$ & 152.93 & 3660 & 456.8 & 120 & 0.012 \\
\hline Isobutene & 58.1 & 3640 & 407.8 & 3 & 0 \\
\hline
\end{tabular}

${ }^{\text {a }}$ GWP: Global Warming Potential (GWP) for 100 years integration

${ }^{\mathrm{b}}$ Ozone Depletion Potential (OPD) relative to R11

Fig. 3 presents the results of net power output for different working fluids in the two proposed systems. Results show that by adding the fuel cell to the system, the net power output is improved significantly. For instance in the case of R245fa as working agent, an increment of $1382 \mathrm{~kW}$ in net output power occurs and $1403 \mathrm{~kW}$ increment in the Isobutene case can be seen. This figure also indicates that Isobutene has higher output power in both cases. 


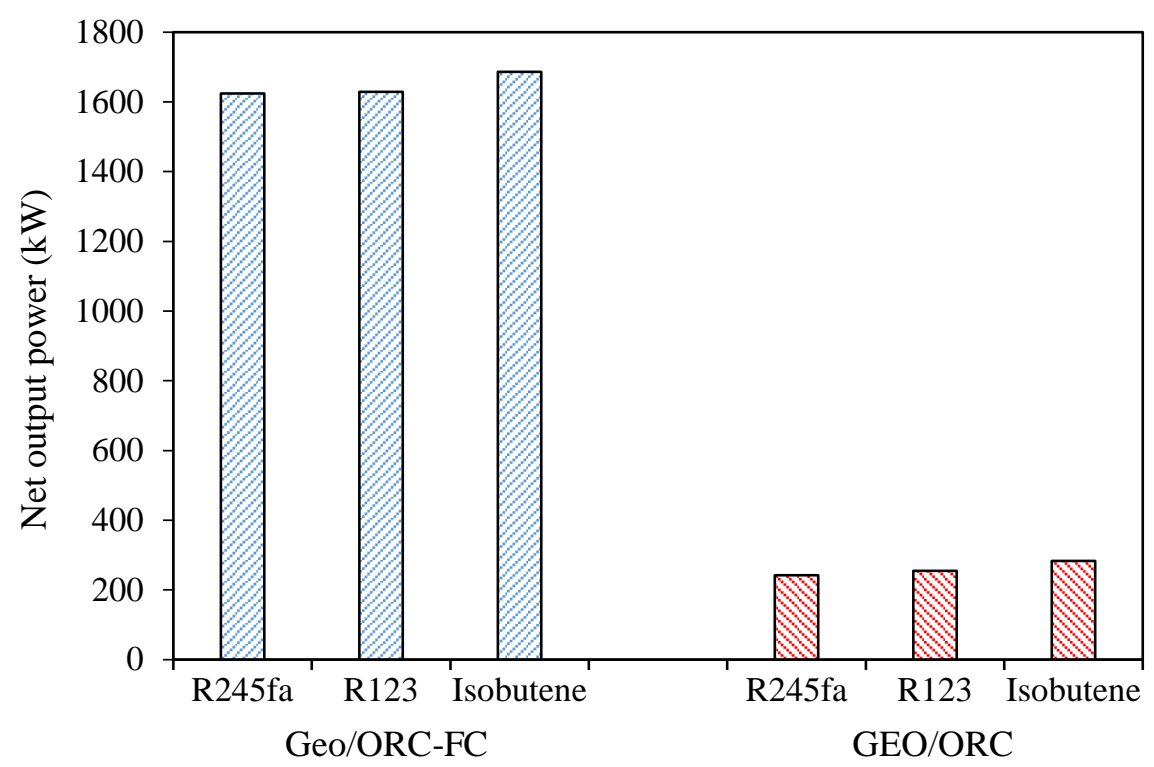

Fig. 3. Comparison of the net power output of both systems with different working fluids

To better understanding the influences of fuel cell employment on the studied system, the energy and exergy efficiencies of both systems for different working fluids are shown in Fig. 4. The results indicate that in both systems, the energy efficiency is less than the exergy efficiency. The main cause for this result goes back to the values of energy and exergy of the geothermal fluid. Given the relatively low geothermal fluid temperature, there is a large difference between the amount of energy and exergy of geothermal fluid. This difference according to the definition of efficiencies results in a huge difference between energy and exergy efficiencies.

Moreover, the comparison of the selected working fluids shows that in both systems namely Geo/ORFC and Geo/ORFC-FC, R123 working fluid has the highest energy and exergy efficiency. For example, the energy and exergy efficiency of Geo/ORFC-FC integrated system with R123 as working fluid are $23.6 \%$ and $36.2 \%$, respectively, and these values for Geo/ORFC integrated system are $4.94 \%$ are $23.77 \%$, respectively. 


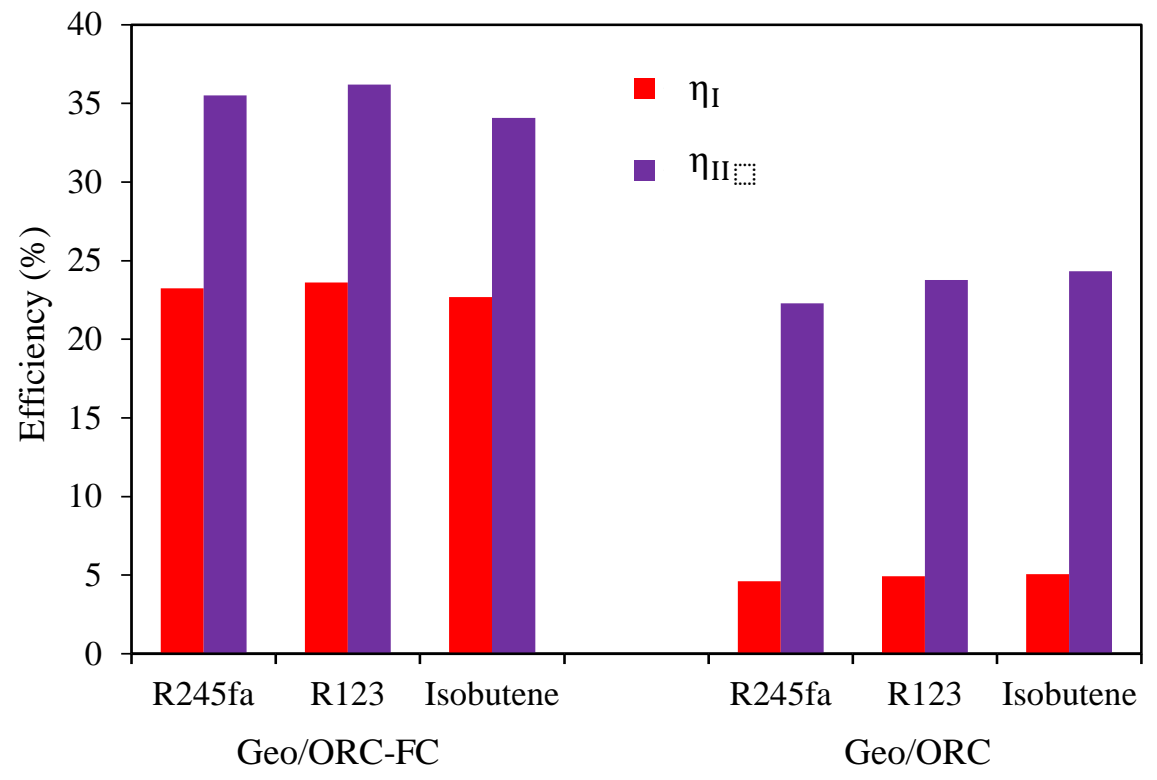

Fig. 4. Energy and exergy efficiencies of both Geo/ORFC system and Geo/ORFC-FC system for different working fluids

The comparison of the total cost rate and exergy destruction rate for two systems configuration is shown in Fig. 5. Results show that the total exergy destruction rate in the Geo/ORFC-FC system is much higher than the Geo/ORFC one, the main cause of large difference of these two parameters is the exergy destruction rate of the fuel cell unit. The results indicate that with R123 as working fluid, the exergy destruction rate of Geo/ORFC-FC system is $2.82 \mathrm{MW}$ that is the lowest value among all working fluid. Furthermore, adding the fuel cell to the Geo/ORFC system with R123 as working fluid the total cost rate of system is $10.3 \mathrm{US} \$ / \mathrm{h}$ which is lower than other working fluid. 


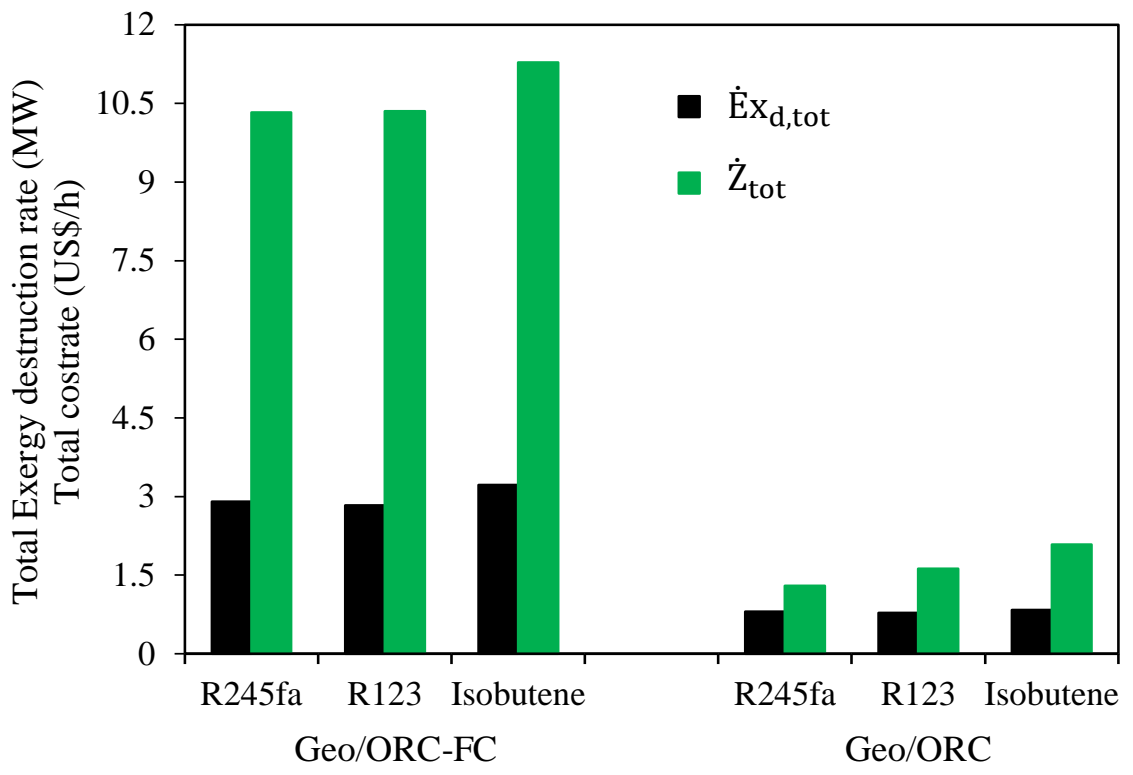

Fig. 5. Comparison of total exergy destruction rate and total cost rate of Geo/ORFC and Geo/ORFC-FC with different working fluid

Exergy destruction rate of each component of the two studied systems can provide better details of system performance. As can be seen (Fig. 6), in most of the two systems components, the exergy destruction rate is equal and there is a significant difference in the fuel cell and evaporator II. 


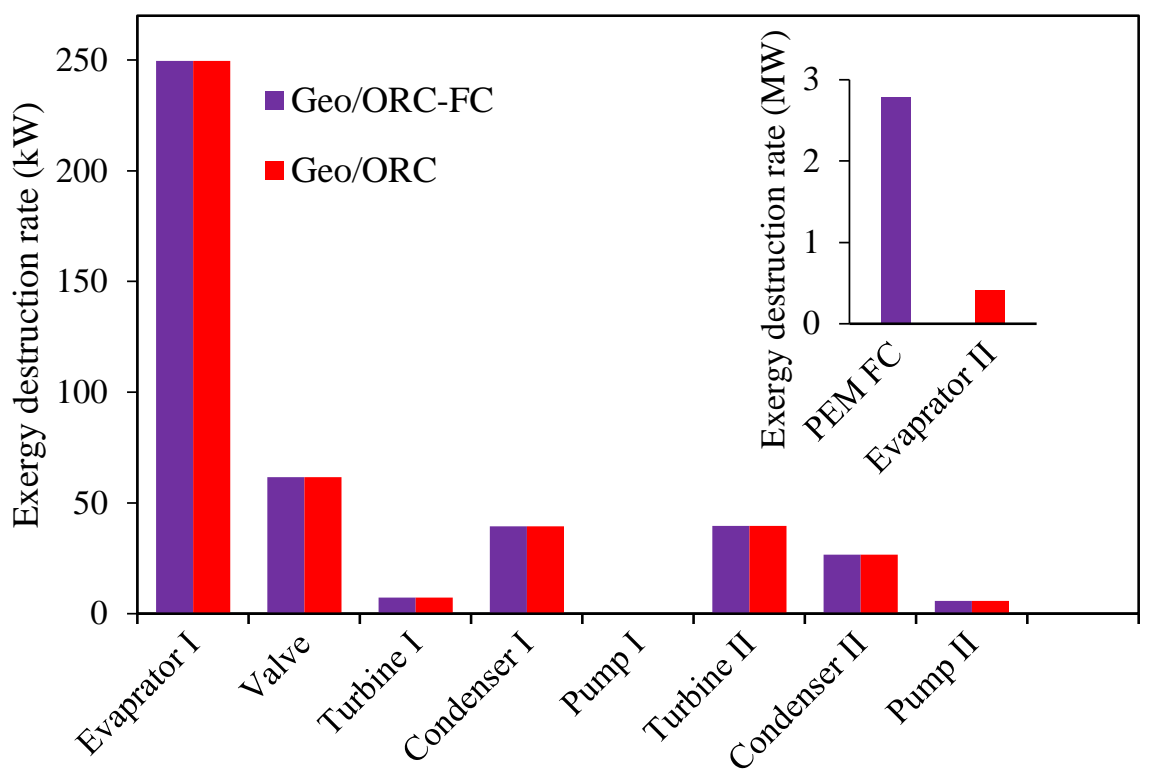

Fig. 6. Exergy destruction rate of different components of the Geo/ORFC and Geo/ORFC-FC systems with R123 as working agent

Better comparison between the two systems is possible by examining the exergy efficiency and the cost rate of each component. Data on the exergy destruction rate for Geo/ORC-FC system are given in Table 4. It is worth to note that in the Geo/ORFC system, the efficiency and cost rate of each component is similar to the Geo/ORFC-FC system and the main difference is between the two systems in Evaporator II, which is just one of the systems have this component.

The results of cost rates indicate that, in most cases, R123 working fluid has the best performance in terms of the cost rate of equipment and in the terms of exergy efficiency. According to the results, condenser I and II for R123 as the working fluid have an exergy efficiency of 5.92\% and $2.66 \%$, respectively. The reason for the low efficiency in these components is that the exergy of the hot stream is given to the cooling fluid with lower temperature, and the exergy destruction in this process is high. 
Table 4. Exergy efficiency and cost rate of different components of studied systems with different working fluids

\begin{tabular}{|c|c|c|c|c|c|c|}
\hline & \multicolumn{3}{|c|}{ Exergy efficiency (\%) } & \multicolumn{3}{|c|}{ Cost rate $(\mathrm{US} \$ / \mathrm{h})$} \\
\hline & Isobutene & R123 & R245fa & Isobutene & $\mathrm{R} 123$ & R245fa \\
\hline Evaporator I & 42.22 & 93.62 & 70.48 & 0.0354 & 0.149 & 0.056 \\
\hline Turbine I & 87.52 & 88.91 & 88.32 & 0.2391 & 0.232 & 0.219 \\
\hline Condenser I & 23.03 & 5.92 & 8.42 & 0.1577 & 0.032 & 0.048 \\
\hline Pump I & 98.92 & 86.95 & 86.23 & 0.0011 & 0.032 & 0.042 \\
\hline Turbine II & 85.25 & 88.67 & 88.08 & 0.8371 & 0.738 & 0.713 \\
\hline Condenser II & 18.82 & 2.66 & 4.03 & 0.7095 & 0.077 & 0.119 \\
\hline Pump II & 84.2 & 86.93 & 86.22 & 0.0401 & 0.012 & 0.012 \\
\hline Flash vessel & - & - & - & 0.006 & 0.006 & 0.006 \\
\hline Fuel cell & 28.92 & 29.47 & 30.01 & 9.07 & 9.07 & 9.12 \\
\hline
\end{tabular}

As it is seen, the Geo/ORFC-FC system performs better in most cases than the Geo/ORFC system. In addition, the results of various working fluids indicate that R123 has the best performance among other fluids. Hence, in the following, the parametric study of the Geo/ORFC-FC system is provided with the R123 working fluid.

\subsection{Parametric study of Geo/ORFC-FC system}

Fig. 7 illustrates the effects of the geothermal source temperature on system operating parameters including energy efficiency, exergy efficiency, and total cost rates of the Geo/ORFC-FC system with R123 working fluid. As can be observed, increasing the temperature of the geothermal source from $100{ }^{\circ} \mathrm{C}$ to $135{ }^{\circ} \mathrm{C}$ increases the overall system cost rate from $8 \mathrm{US} \$ /$ h to 11.33 US $\$ / \mathrm{h}$. 
Likewise, the increase in this parameter leads to a decrease in energy efficiency and exergy efficiency, which is related to the increase of the amount of the denominator in the definition of efficiencies (Eqs (57) and (59)). On the other hand, although the increase of geothermal heat source temperature according to Fig. 8 would increase the work of the pump II, it would increase the output of the turbines and fuel cell power generation. It worth noting that the power consumption of pump I is negligible, with no significant changes.

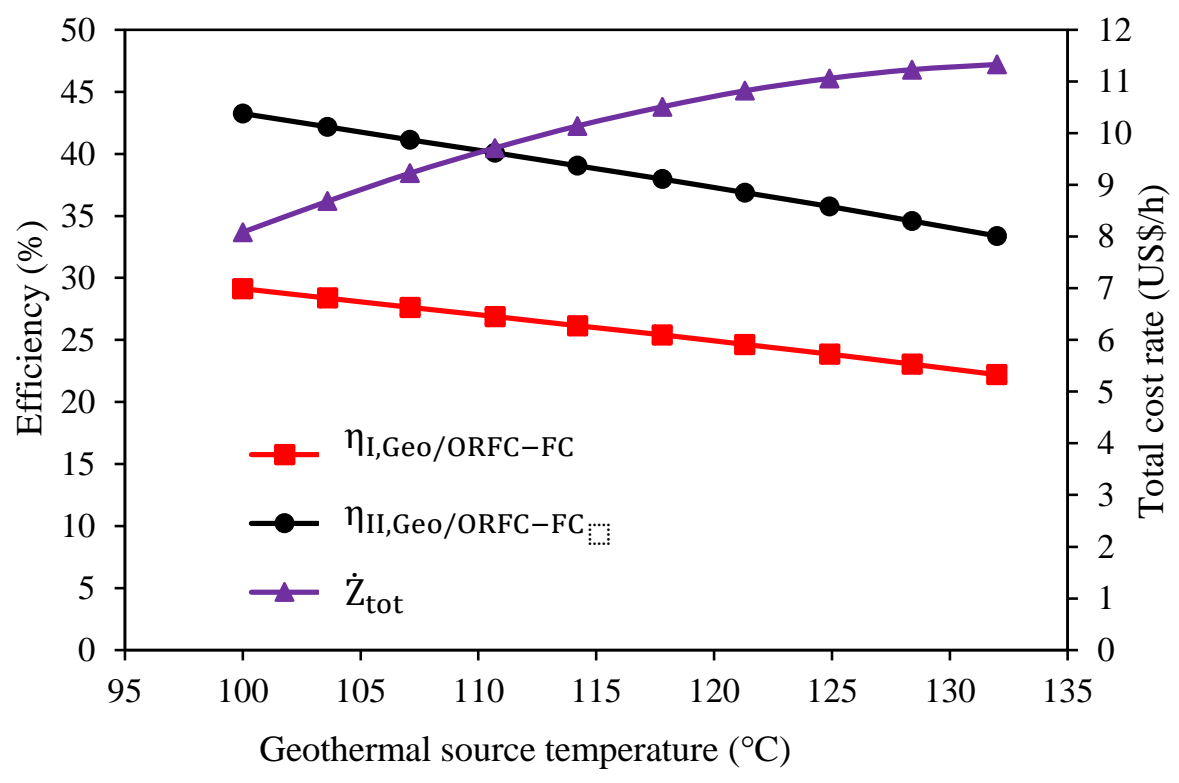

Fig. 7. The effects of geothermal source temperature on the energy and exergy efficiencies and total cost rate of the Geo/ORFC-FC system 


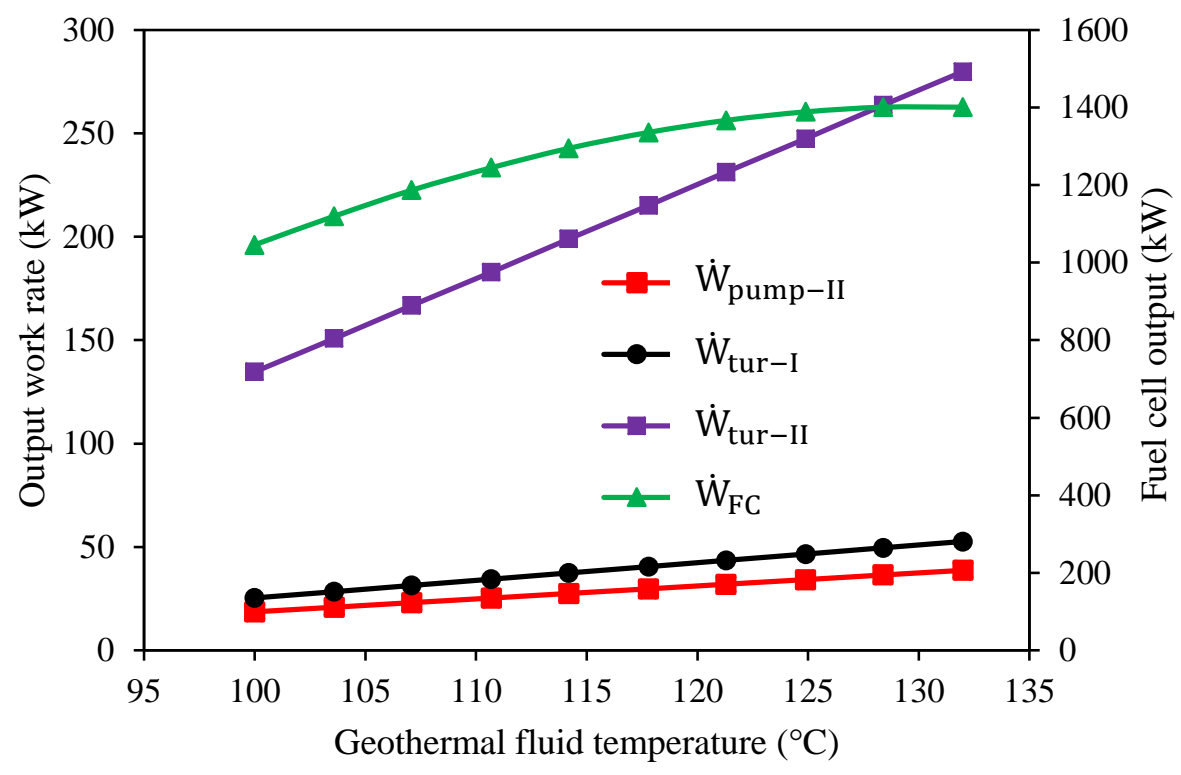

Fig. 8. The effects of geothermal source temperature on the outputs of Geo/ORFC-FC system and pump's input power

The effects of the flash vessel pressure on the efficiencies and the total cost rate are shown in Fig. 9. In all cases, as shown, the increase in this pressure leads to an increase in the energy and exergy efficiencies as well as the overall cost rates. 


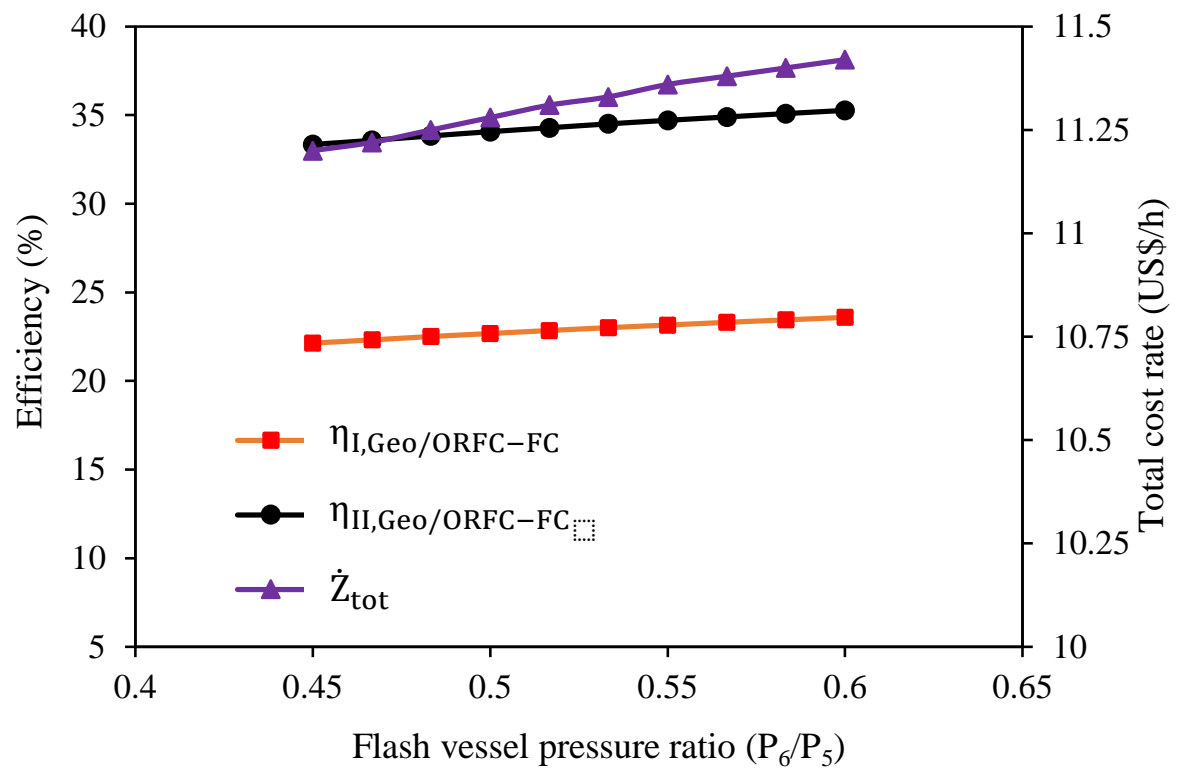

Fig. 9. Variation of energy and exergy efficiencies and total cost rate of Geo/ORFC-FC with flash

pressure ratio

An increase in the pressure of flash vessel also allows increasing the turbine II output power about $146.1 \mathrm{~kW}$ with no change in other outputs of the Geo/ORFC-FC system. This enhancement is due to an increase in the mass flow rate of the inflow into the turbine II. The power output of the turbine depends on turbine mass flow rate and this parameter is directly related to the liquid fraction in the flash chamber. The increase in the pressure vessel increases the amount of liquid fraction as well as liquid fraction (Fig. 10). 


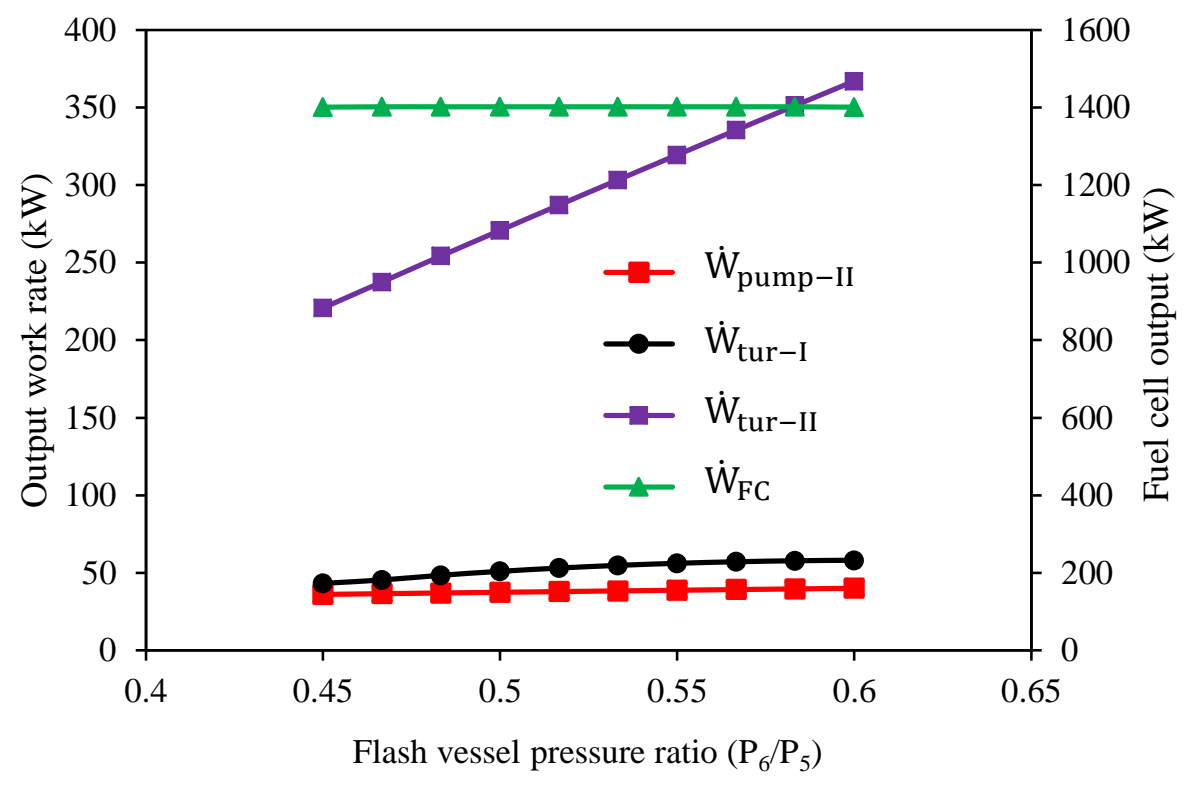

Fig. 10. The variation of turbine output power and pump's input power with flash vessel pressure ratio

The effects of fuel cell pressure variations on the Geo/ORC-FC system performance are shown in Fig. 11. As can be seen from the results, the increase in fuel cell pressure reduces the efficiency of the first and second law efficiency of the system to a small extent, but does not affect the overall system cost rate. 


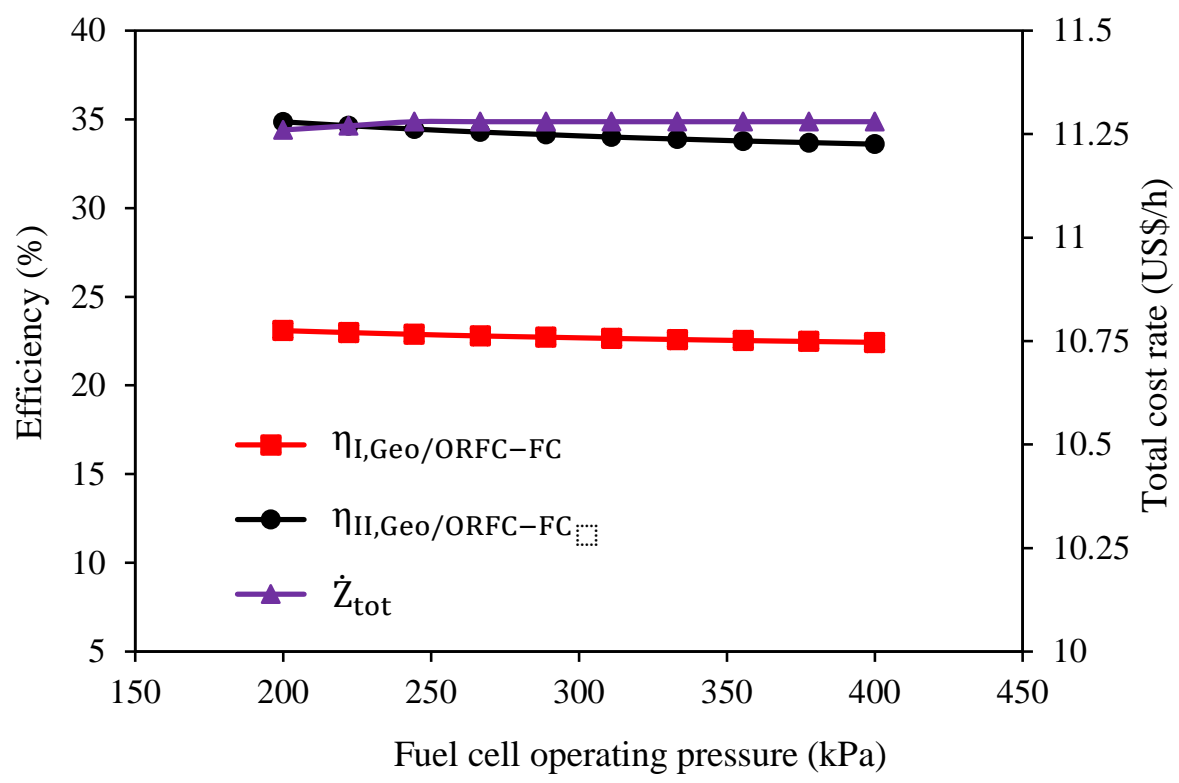

Fig. 11. The effect of fuel cell pressure changes on the energy and exergy efficiencies and overall cost rate of system

The results show that a decrease in both energy and exergy efficiencies of the studied system with an increase in the fuel cell pressure is due to the fact that increasing the pressure in the fuel cell increases the fuel consumption in the fuel cell from $18.44 \mathrm{~mol} / \mathrm{s}$ to $19.23 \mathrm{~mol} / \mathrm{s}$. As a result, it can be stated that with the constant net power output of the system and increasing the hydrogen consumption, we can see a decrease in efficiencies (Fig. 12). 


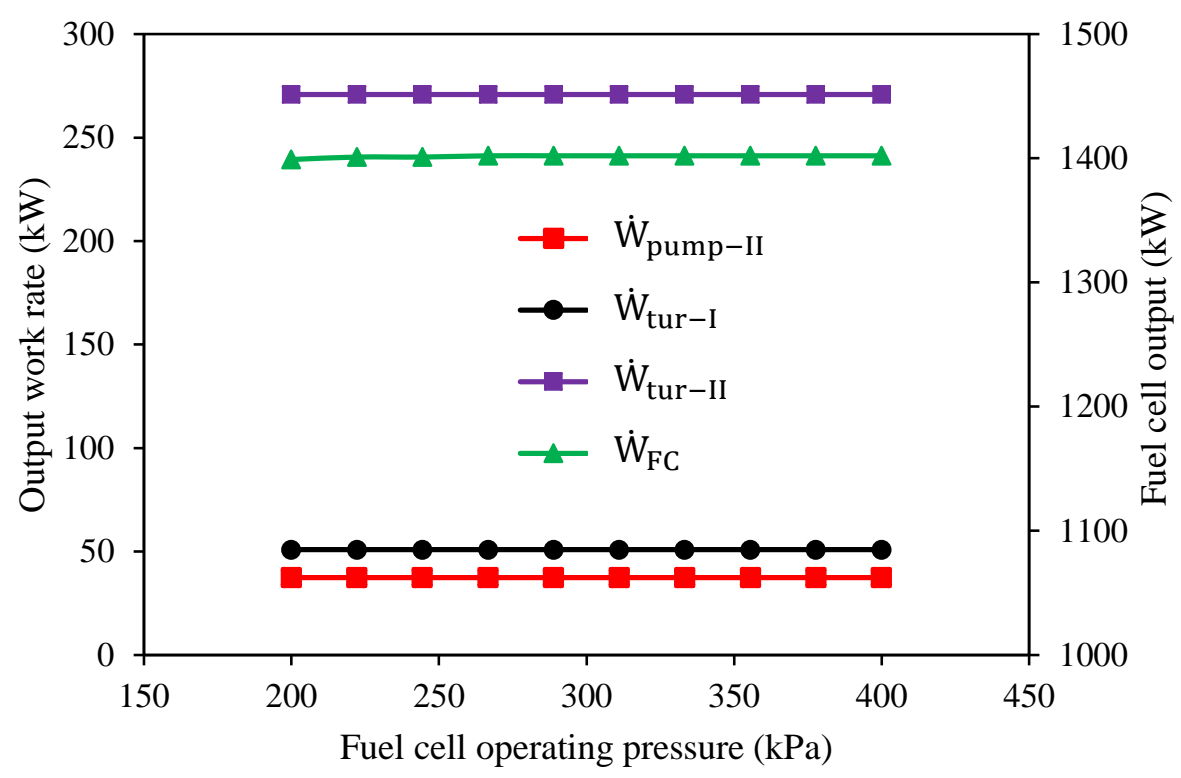

Fig. 12. The effects of fuel cell operating pressure on the system outputs and pump's input power

Following the investigation of the influences of important parameters on the Geo/ORFC-FC system under study, the impact of the ORFC maximum pressure $\left(P_{4}\right)$ is considered in Fig 13 and Fig 14. The results show that an increase in the ORFC maximum pressure reduces the overall cost rate of the system, which goes back to the operation cost of the fuel cell unit (i.e., due to reduced fuel cell production capacity and, consequently, reduction of the cost of the fuel cell input fuel). It also increases the energy and exergy efficiencies of the system simultaneously. The energy and exergy efficiencies increase by $4.03 \%$ and $7.56 \%$, respectively. This increase in efficiency is due to a reduction in the hydrogen consumption of the fuel cell, which, with a defined ratio for efficiency, results in an increase in the efficiency.

Fig. 14 illustrates the changes of output and input power, which indicates that increasing the ORFC maximum pressure reduces the power output of the fuel cell, but increasing the generated power of the turbine and reducing the consumption of the pump II will ultimately increase the system output power by $47.8 \mathrm{~kW}$. 


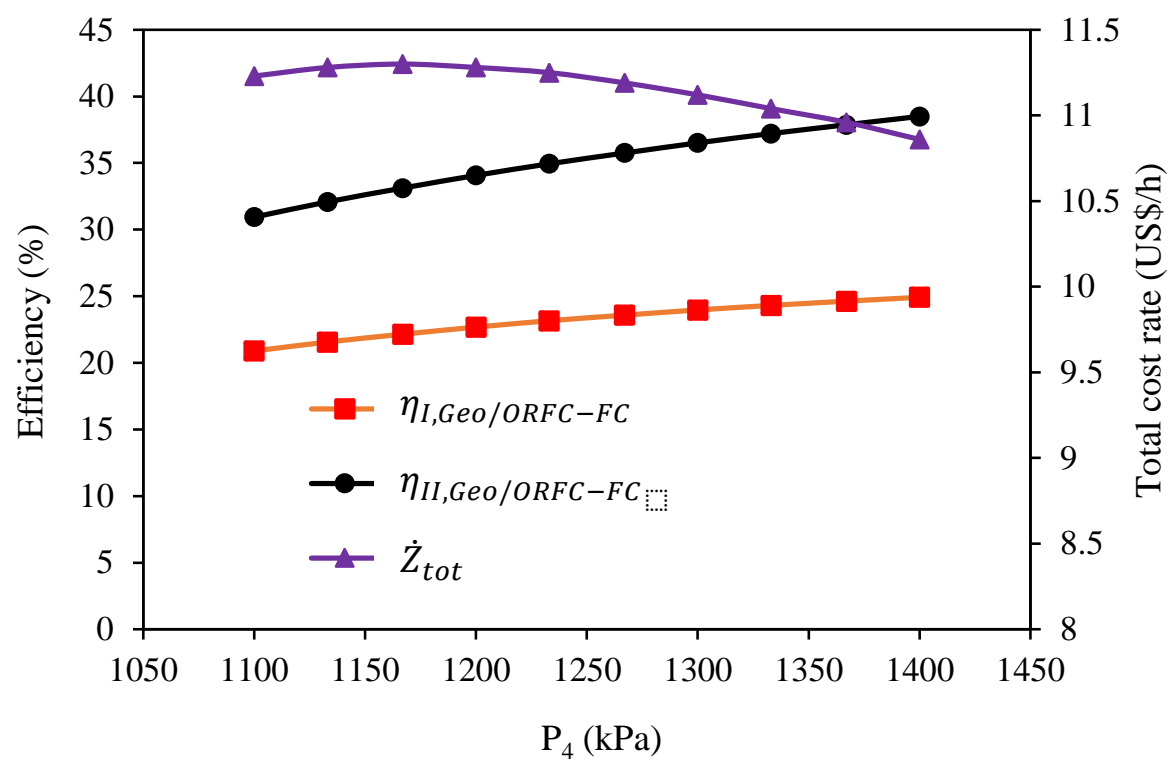

Fig. 13. The effects of ORFC maximum pressure on the efficiencies and overall cost rate of the studied system

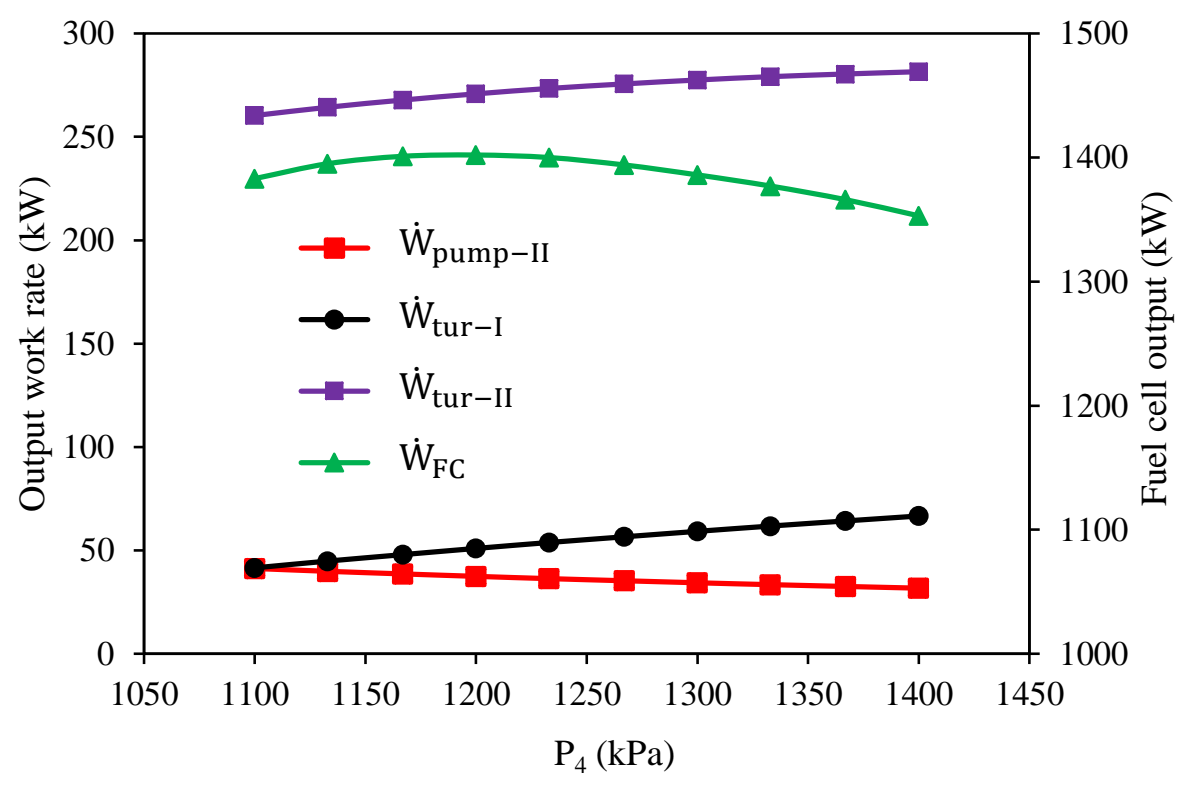

Fig. 14. The effects of ORFC maximum pressure on the turbine output and pump's input power 
Analysis of the results of the parametric analysis shows that the considered variables have different effects on the output power, efficiencies, and overall system cost rate. With regards to the above mentioned results, multi-criteria optimization can assist us to determine the optimal state of the Geo/ORC-FC system. Thus, selecting objective functions have a significant role in determining the optimal state of the system. An important point in the multi-objective optimization is to see if objective functions are conflicting. A closer examination of the results reveals that among different criteria, the net output power, and the overall cost rate of the system are the two good candidates to be considered as objective functions. From previous sections, it was observed that by changing the geothermal source temperature, flash tank pressure, fuel cell pressure and maximum pressure of the ORFC have better influence on system performance Therefore, because of the this, the net output power and the total cost of the system are considered as objective functions. The system optimization results are presented below.

\subsection{Multi objective optimization}

Multi-objective optimization results are presented in Fig. 15. The set of points obtained through this optimization is based on the trade-off between two objective functions, (i.e., the total cost rate

$\left(\dot{Z}_{t o t}\right)$ and net output power $\left.\left(\dot{W}_{\text {net }}\right)\right)$, therefore all the points introduced on the Pareto curve (Fig. 15) can be selected as the optimal final point.

The points excluded in the figure correspond to a particular state of the optimal states of the system. For example, points $A$ and $C$ correspond to the single-objective optimization with the total cost rate and net power output as sole objective functions, respectively. Additionally, in this chart, "best point" refers to the point where two objective functions have their best values. Clearly, the "Best point" is not a real point on the Pareto curve and it is a hypothesis point. In multi-objective 
optimization problems, the points close to the best point are said to be best final points as they have their both objective functions in their optimal reasonable ranges. With these interpretations, it can be said that point $B$ has the smallest distance with the virtual point of the "Best point".

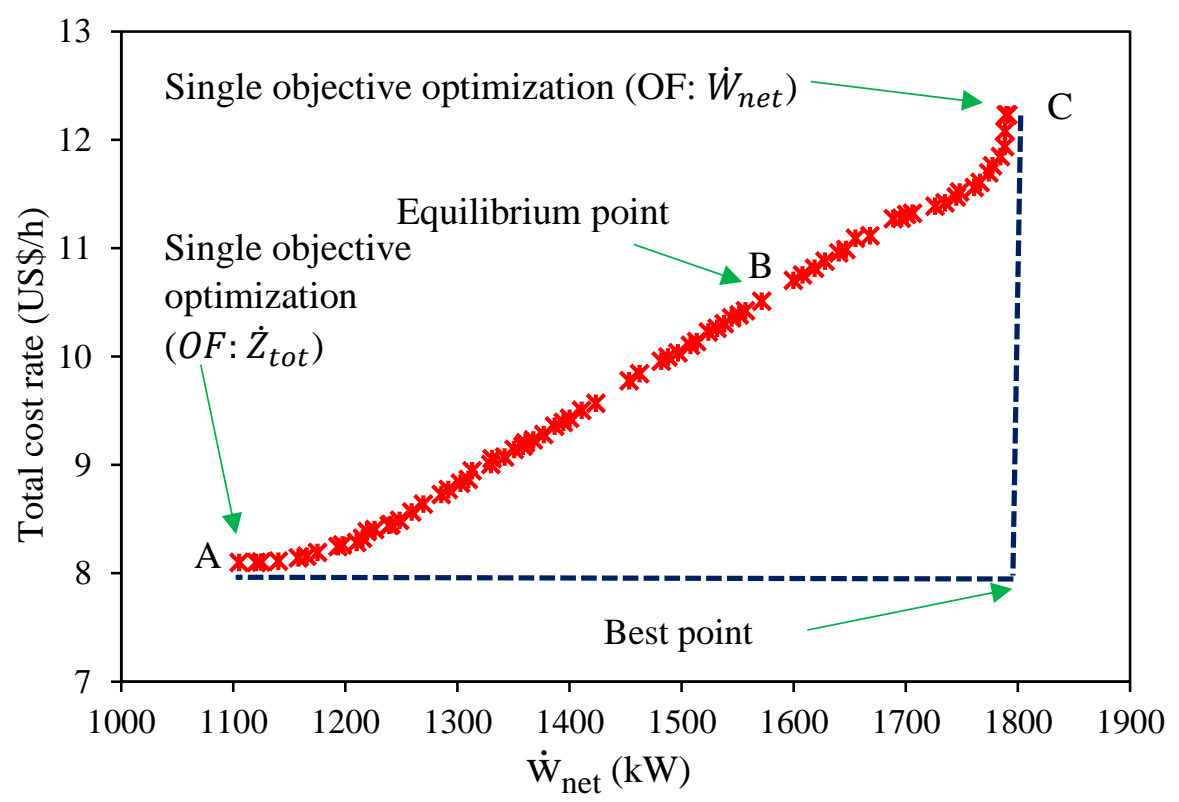

Fig. 15. Pareto plot for optimizing the Geo/ORFC-FC system based on the total cost rate and net output power as objective functions

The characteristics of the points set on the Pareto curve, including the decision variables and the objective functions, are shown in Table 5.

Table 5. The specifications of the optimum points shown on the Pareto chart

\begin{tabular}{|c|c|c|c|c|c|c|}
\hline Point & $T_{1}$ & $r_{\text {flash }}$ & $P_{F C}$ & $P_{4}$ & $\dot{W}_{\text {net }}$ & $\dot{Z}_{\text {tot }}$ \\
& $\left({ }^{\circ} \mathrm{C}\right)$ & $(-)$ & $(\mathrm{kPa})$ & $(\mathrm{kPa})$ & $(\mathrm{kW})$ & $(\mathrm{US} \$ / \mathrm{h})$ \\
\hline$A$ & 100 & 0.49 & 230 & 1283.7 & 1120.4 & 8.10 \\
\hline$B$ & 116 & 0.55 & 230 & 1208.4 & 1571.1 & 10.51 \\
\hline
\end{tabular}




\begin{tabular}{|l|l|l|l|l|l|l|}
\hline$C$ & 132 & 0.6 & 318 & 1194.7 & 1790.9 & 12.23 \\
\hline
\end{tabular}

Different criteria can be considered by the system designer to select the optimal final solution. One of these criteria is the investigation of distribution of decision variables in their allowable range. The graphs shown in Fig. 16 depict the distribution of the values of the decision variables at the optimal points obtained by the Pareto optimization method. Dashed lines also display the variable upper and lower limits.

In the case where the values of each variable are completely distributed within the range of variations, it means that with the changes of this parameter, the two objective functions are conflicting with each other. For example, a study of the temperature of the geothermal source shows that the variation of this parameter is distributed sporadically throughout the entire range, while for fuel cell pressure it is seen that the points are distributed around $2.4 \mathrm{kPa}$. Examining these parameters allows the designer to select some design parameters, and selecting other decision makers can be based on criteria that are defined by him. 

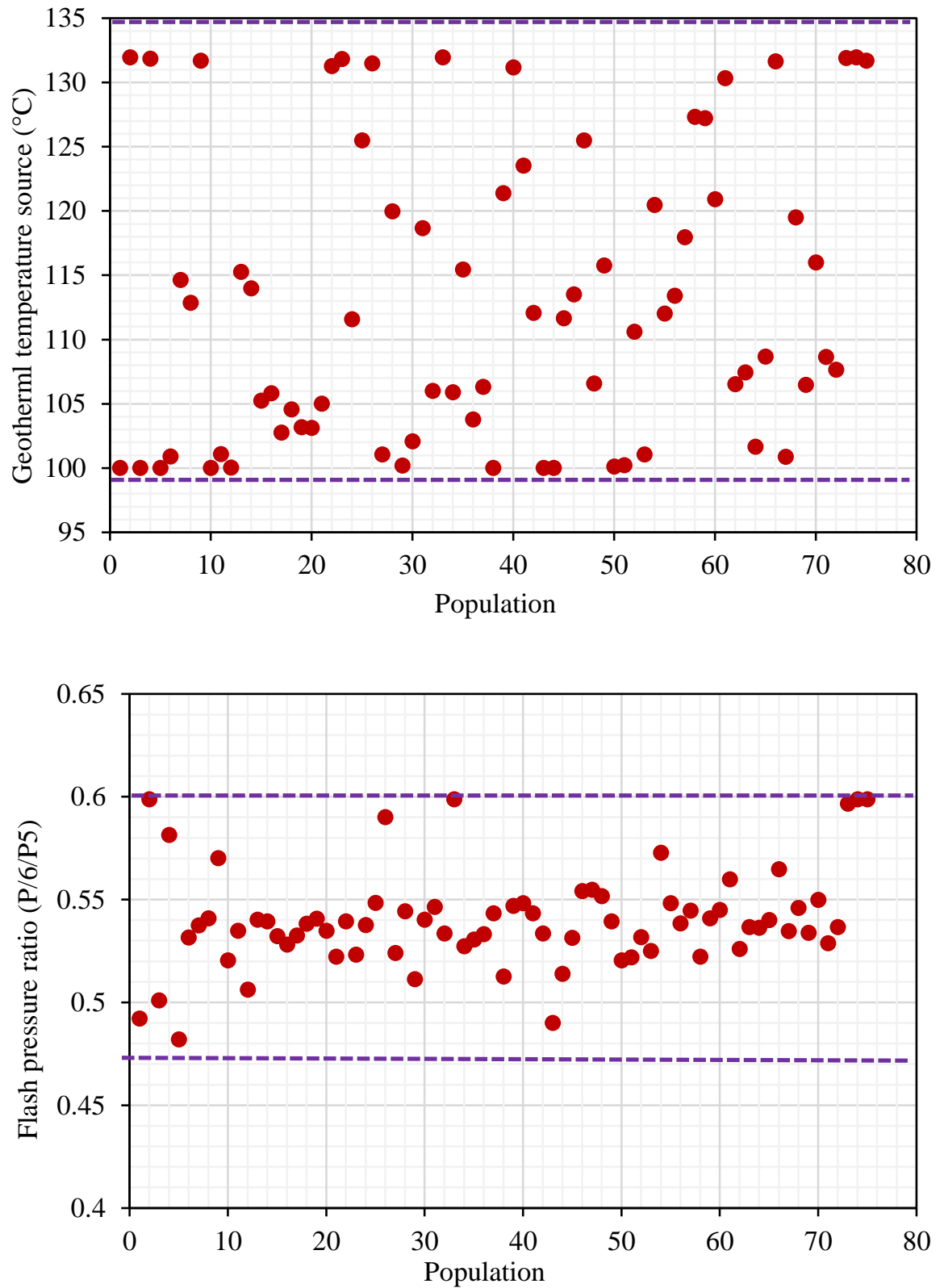

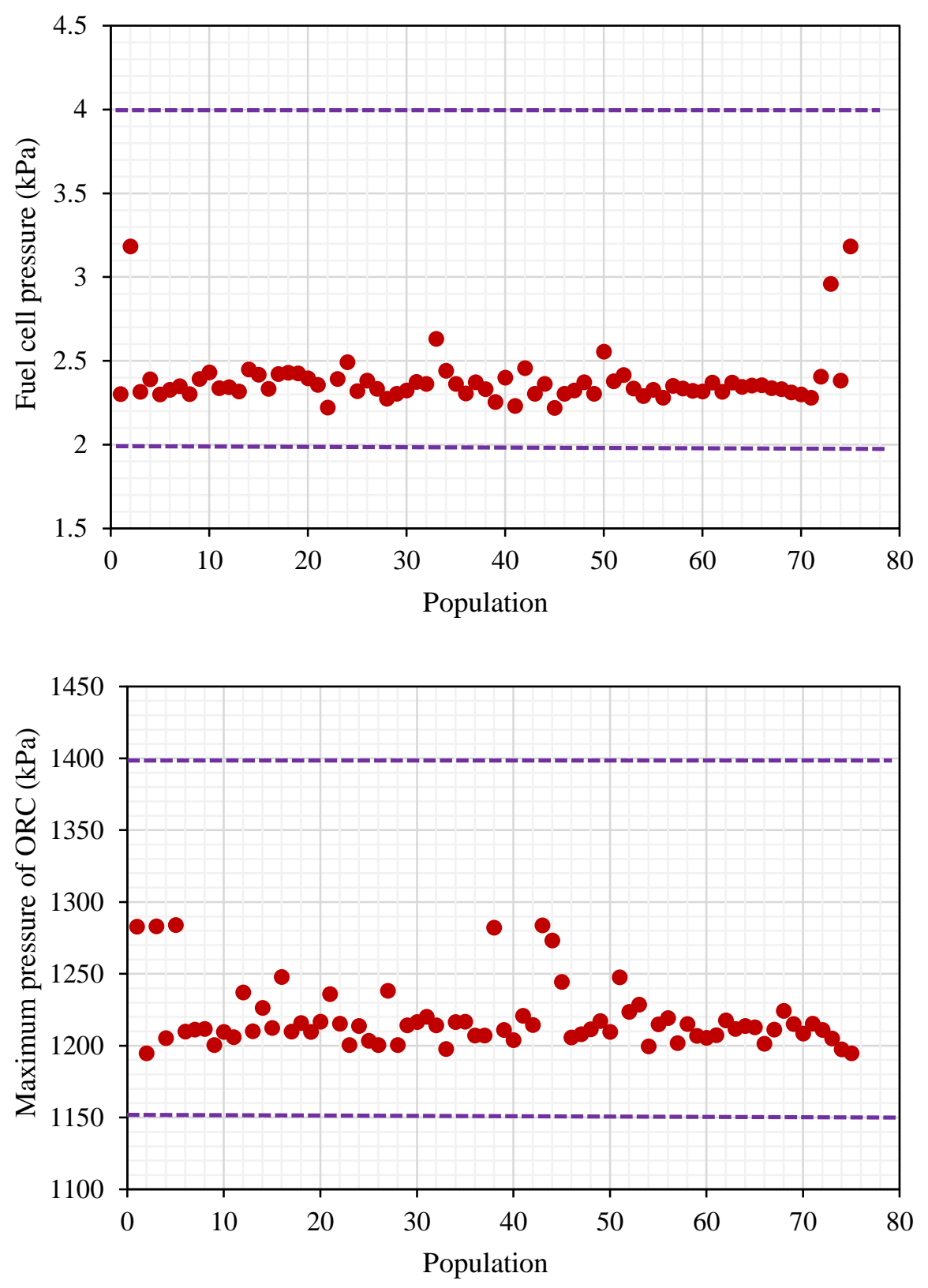

Fig. 16. Scatter distribution of the decision variable values in the optimal points proposed by multiobjective optimization

\section{Conclusion}

In the current research study, an organic Rankine flash cycle with geothermal energy derive is investigated. To improve the system performance, the fuel cell waste heat is used instead of low- 
temperature geothermal source. Using thermodynamic and economic modeling and conducting energy, exergy and economic analysis, the performance of two suggested systems namely Geo/ORC and Geo/ORC-FC was compared. For a better understanding the influence of different variables on the considered cycle performance, a parametric study on the Geo/ORC-FC is performed. Due to the nature of multi-objective optimization and regarding parametric study, the total net output power, and total cost rate of system considered as objective functions. In summary, the following highlights are the main results of the present study:

- The results of energy analysis of the suggested systems show that adding the PEM-FC to the Geo/ORFC system improves the performance of the system in terms of energy and exergy efficiencies and power output.

- Among the employed fluids, the results show that the R123 organic fluid has a better performance in both systems.

- The energy efficiency for Geo/ORFC and Geo/ORFC-FC with R123 are 23.6\%, 4.94\% and the value of exergy efficiency are $36.2 \%$ and $23.77 \%$.

- However adding PEM-FC impose a cost rate about $8.27 \mathrm{US} \$ / \mathrm{h}$, it improve the total net output of the system about $1403 \mathrm{~kW}$ in the case R123 is working fluid.

- The result of parametric study of Geo/ORFC-FC system represents that there is appropriate conflict between two defined objective functions namely, total net power output and total cost rate with changing four decision variables.

- Performed multi-criteria optimization represents that the optimum value of decision variables regarding considered objective functions are: $T_{1}=116^{\circ} \mathrm{C}, r_{\text {flash }}=0.55, P_{F C}=$ $230 \mathrm{kPa}$, and $P_{4}=1208.4 \mathrm{kPa}$. 


\section{Appendix}

PEM fuel cell includes an acidic water-base polymer membrane as electrolyte and Platinum-based electrodes. This type of power generation device operates in relatively low temperature (below $100^{\circ} \mathrm{C}$ ). Perfluorosulfonic acid (PFSA) is the commercially available membrane also Nafion is the most common one. The microporous layer (MPL) acts as an interface zone between the relatively large feature size of the gas diffusion layer (GDL) and the much smaller catalyst particles. Commonly MPL is made from carbon or graphite. The GDL is responsible for providing the pathway for transport of the reactant gas from flow channels to the catalyst layer [40].

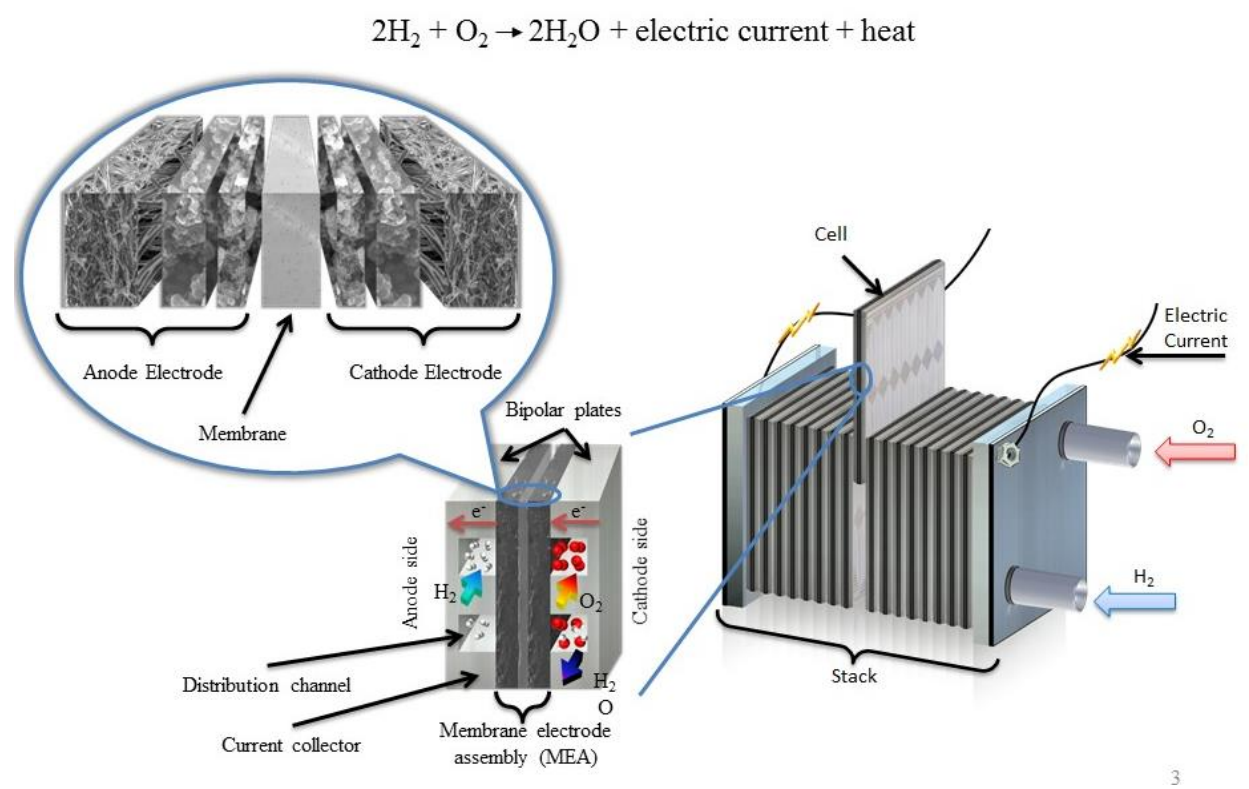

Fig. A1. The schematic of a stack PEM-FC and detail of a cell

\section{Acknowledgment}

This research is partially supported by NSFC (5197090691), Mindu scholar of Laboratory of Hydraulic Engineering Simulation and Safety-Tianjin University (HESS-1901).

\section{Reference}


[1] Anderson A, Rezaie B. Geothermal technology: Trends and potential role in a sustainable future. Appl Energy 2019;248:18-34.

[2] Glassley WE. Geothermal energy: Renewable energy and the environment. 2nd ed. CRC Press; 2010.

[3] DiPippo R. Geothermal Power Plants: Principles, Applications, Case Studies and Environmental Impact: Fourth Edition. Elsevier B.V.; 2015.

[4] Barbier E. Nature and technology of geothermal energy: A review. Renew Sustain Energy Rev 1997;1:1-69.

[5] Islam S, Dincer I. Development, analysis and performance assessment of a combined solar and geothermal energy-based integrated system for multigeneration. Sol Energy 2017;147:328-43.

[6] Ganjehsarabi H. Mixed refrigerant as working fluid in Organic Rankine Cycle for hydrogen production driven by geothermal energy. Int J Hydrogen Energy 2019;44:18703-11.

[7] Karapekmez A, Dincer I. Thermodynamic analysis of a novel solar and geothermal based combined energy system for hydrogen production. Int J Hydrogen Energy 2018;177:339_ 49.

[8] Yilmaz C. Thermoeconomic modeling and optimization of a hydrogen production system using geothermal energy. Geothermics 2017;65:32-43.

[9] Akrami E, Chitsaz A, Nami H, Mahmoudi SMS. Energetic and exergoeconomic assessment of a multi-generation energy system based on indirect use of geothermal energy. Energy 2017;124:625-39.

[10] Yuksel YE, Ozturk M, Dincer I. Energetic and exergetic performance evaluations of a geothermal power plant based integrated system for hydrogen production. Int J Hydrogen Energy 2018;43:78-90.

[11] Yuksel YE, Ozturk M, Dincer I. Thermodynamic analysis and assessment of a novel integrated geothermal energy-based system for hydrogen production and storage. Int $\mathbf{J}$ Hydrogen Energy 2018;43:4233-43.

[12] Kianfard H, Khalilarya S, Jafarmadar S. Exergy and exergoeconomic evaluation of hydrogen and distilled water production via combination of PEM electrolyzer, RO desalination unit and geothermal driven dual fluid ORC. Energy Convers Manag 
2018;177:339-49.

[13] Yilmaz C, Kanoglu M. Thermodynamic evaluation of geothermal energy powered hydrogen production by PEM water electrolysis. Energy 2014;69:592-602.

[14] Ebadollahi M, Rostamzadeh H, Pedram MZ, Ghaebi H, Amidpour M. Proposal and assessment of a new geothermal-based multigeneration system for cooling, heating, power, and hydrogen production, using LNG cold energy recovery. Renew Energy 2019;135:66-87.

[15] Boyaghchi FA, Chavoshi M, Sabeti V. Optimization of a novel combined cooling, heating and power cycle driven by geothermal and solar energies using the water/CuO (copper oxide) nanofluid. Energy 2015;91:685-99.

[16] Cao F, Li H, Ma Q, Zhao L. Design and simulation of a geothermal-solar combined chimney power plant. Energy Convers Manag 2014;84:186-95.

[17] Missimer TM, Kim YD, Rachman R, Ng KC. Sustainable renewable energy seawater desalination using combined-cycle solar and geothermal heat sources. Desalin Water Treat 2013;51:1161-70.

[18] Outeiro MT, Chibante R, Carvalho AS, de Almeida AT. A new parameter extraction method for accurate modeling of PEM fuel cells. Int J Energy Res 2009;33:978-88.

[19] Ahmadi P, Dincer I, Rosen MA. Energy and exergy analyses of hydrogen production via solar-boosted ocean thermal energy conversion and PEM electrolysis. Int J Hydrogen Energy 2013;34:1795-805.

[20] Bendaikha W, Larbi S, Bouziane M. Feasibility study of hybrid fuel cell and geothermal heat pump used for air conditioning in Algeria. Int J Hydrogen Energy 2011;36:4253-61.

[21] Ratlamwala TAH, Gadalla MA, Dincer I. Thermodynamic analyses of an integrated PEMFC-TEARS-geothermal system for sustainable buildings. Energy Build 2012;44:7380.

[22] Al-Nimr MA, Bukhari M, Mansour M. A combined CPV/T and ORC solar power generation system integrated with geothermal cooling and electrolyser/fuel cell storage unit. Energy 2017;133:513-24.

[23] Sigurvinsson J, Mansilla C, Lovera P, Werkoff F. Can high temperature steam electrolysis function with geothermal heat? Int J Hydrogen Energy 2007;32:1174-82.

[24] Frazzica A, Briguglio N, Sapienza A, Freni A, Brunaccini G, Antonucci V, et al. Analysis 
of different heat pumping technologies integrating small scale solid oxide fuel cell system for more efficient building heating systems. Int J Hydrogen Energy 2015;40:14746-56.

[25] Yilmaz C, Koyuncu I, Alcin M, Tuna M. Artificial Neural Networks based thermodynamic and economic analysis of a hydrogen production system assisted by geothermal energy on Field Programmable Gate Array. Int J Hydrogen Energy 2019;44:17443-59.

[26] Dincer I, Rosen MA, Ahmadi P. Optimization of energy systems. 1st ed. Wiley; 2017.

[27] Barbir F, Gorgun H, Wang X. Relationship between pressure drop and cell resistance as a diagnostic tool for PEM fuel cells. J Power Sources 2005;141:96-101.

[28] Chen PC. The dynamics analysis and controller design for the PEM fuel cell under gas flowrate constraints. Int J Hydrogen Energy 2011;36:3110-22.

[29] Khanmohammadi S, Saadat-Targhi M. Thermodynamic and economic assessment of an integrated thermoelectric generator and the liquefied natural gas production process. Energy Convers Manag 2019;185:603-10.

[30] Khanmohammadi S, Saadat-Targhi M. Thermodynamic and economic analyses and multiobjective optimization of harvesting waste heat from a biomass gasifier integrated system by thermoelectric generator. J Clean Prod 2019;224:346-60.

[31] Ameri M, Ahmadi P, Khanmohammadi S. Exergy analysis of a $420 \mathrm{MW}$ combined cycle power plant. Int J Energy Res 2008;32:175-83.

[32] Kotas TJ. The Exergy Method of Thermal Plant Analysis. Butterworth-Heinemann; 1985.

[33] Lake A, Rezaie B, Beyerlein S. Use of exergy analysis to quantify the effect of lithium bromide concentration in an absorption chiller. Entropy 2017;19:156.

[34] Khanmohammadi S, Goodarzi M, Khanmohammadi S, Ganjehsarabi H. Thermoeconomic modeling and multi-objective evolutionary-based optimization of a modified transcritical CO2 refrigeration cycle. Therm Sci Eng Prog 2018;5:86-96.

[35] Safari F, Dincer I. Development and analysis of a novel biomass-based integrated system for multigeneration with hydrogen production. Int J Hydrogen Energy 2019;44:3511-26.

[36] Khanmohammadi S, Atashkari K. Modeling and multi-objective optimization of a novel biomass feed polygeneration system integrated with multi effect desalination unit. Therm Sci Eng Prog 2018;8:269-83.

[37] Lee HY, Park SH, Kim KH. Comparative analysis of thermodynamic performance and 
optimization of organic flash cycle (OFC) and organic Rankine cycle (ORC). Appl Therm Eng 2016;100:680-90.

[38] Nemati A, Nami H, Yari M. Assessment of different configurations of solar energy driven organic flash cycles (OFCs) via exergy and exergoeconomic methodologies. Renew Energy 2018;115:1231-48.

[39] Ju H, Wang C. Experimental Validation of a PEM Fuel Cell Model by Current Distribution Data 2004:1954-60.

[40] Zhang J. PEM fuel cell electrocatalysts and catalyst layers: Fundamentals and applications. 1st ed. Springer; 2008.

\section{Appendix}

Table A.1. The cost function of various components of Geo/ORFC and Geo/ORFC-FC systems

\begin{tabular}{|c|c|c|}
\hline Component & Cost function & Auxiliary relation \\
\hline Evaporator I & $Z_{E v a-I}=309.14\left(A_{E v a-I}\right)^{0.85}$ & $\begin{array}{l}L M T D_{\text {Evap }}=\frac{(T[1]-T[5])-(T[2]-T[4])}{\operatorname{Ln}\left(\frac{T[1]-T[5]}{T[2]-T[4]}\right)} \\
\dot{Q}_{\text {eva-I }}=U_{\text {Evap }-I} * A_{E v a} * L M T D_{E v a}\end{array}$ \\
\hline Turbine I & $Z_{\text {tur-I }}=4750\left(\dot{W}_{\text {tut }-I}\right)^{0.75}$ & - \\
\hline Condenser I & $Z_{\text {cond-I }}=309.14 *\left(A_{\text {cond-I }}\right)^{0.85}$ & $\begin{array}{l}L M T D_{\text {cond }-I}=\frac{(T[8]-T[16])-(T[9]-T[15])}{\operatorname{Ln}\left(\frac{T[8]-T[16]}{T[9]-T[15]}\right)} \\
Q_{\text {cond }-I}=U_{\text {cond }-I} * A_{\text {cond }-I} * L M T D_{\text {cond }-I}\end{array}$ \\
\hline Pump I & $Z_{\text {pump-I }}=3500 *\left(\dot{W}_{\text {pump-I }}\right)^{0.41}$ & - \\
\hline Evaporator II & $Z_{E v a-I I}=309.14\left(A_{E v a-I I}\right)^{0.85}$ & $\begin{array}{l}L_{M T D_{\text {eva-II }}}=\frac{(T[19]-T[11])-(T[20]-T[10])}{\operatorname{Ln}\left(\frac{T[19]-T[11]}{T[20]-T[10]}\right)} \\
Q_{\text {eva-II }}=U_{\text {eva-II }} * A_{\text {eva-UU }} * L M T D_{\text {eva }-I I}\end{array}$ \\
\hline Turbine II & $Z_{\text {tur-II }}=4750 *\left(\dot{W}_{\text {tur-II }}\right)^{0.75}$ & - \\
\hline Condenser II & $Z_{\text {cond-II }}=309.14 *\left(A_{\text {cond }_{2}}\right)^{0.85}$ & $\begin{array}{l}L M T D_{\text {cond-II }}=\frac{(T[12]-T[18])-(T[13]-T[17])}{\operatorname{Ln}\left(\frac{T[12]-T[18]}{T[13]-T[17]}\right)} \\
Q_{\text {cond-II }}=U_{\text {con-II }} * A_{\text {cond-II }} * L M T D_{\text {cond }-I I}\end{array}$ \\
\hline
\end{tabular}




\begin{tabular}{|c|c|c|}
\hline Pump II & $Z_{\text {pump-II }}=3500 *\left(\dot{W}_{\text {pump-II }}\right)^{0.41}$ & - \\
\hline PEM-FC & $Z_{P E M-F C}=2500 * \dot{W}_{P E M-F C}$ & - \\
\hline
\end{tabular}

